\title{
The Effectiveness and Efficiency of Disease Management Programs for Patients with Chronic Diseases
}

\author{
Akinori Hisashige ${ }^{1}$ \\ ${ }^{1}$ Institute of Healthcare Technology Assessment, Tokushima, Japan \\ Corresponding: Akinori Hisashige, Institute of Healthcare Technology Assessment, 2-24-10, Shomachi, \\ Tokushima 770-0044, Japan. Tel: 81-88-631-3313. Fax: 81-88-631-3313. E-mail: akih@k3.dion.ne.jp
}

Received: November 2, 2012 Accepted: November 19, 2012 Online Published: November 27, 2012

doi:10.5539/gjhs.v5n2p27 URL: http://dx.doi.org/10.5539/gjhs.v5n2p27

\begin{abstract}
Objective: Disease management (DM) approach is increasingly advocated as a means of improving effectiveness and efficiency of healthcare for chronic diseases. To evaluate the evidence on effectiveness and efficiency of DM, evidence synthesis was carried out.

Methods: To locate eligible meta-analyses and systematic reviews, we searched Medline, EMBASE, the Cochrane Library, SCI-EXPANDED, SSCI, A\&HCI, DARE, HTA and NHS EED from 1995 to 2010. Two reviewers independently extracted data and assessed a study quality.

Results: Twenty-eight meta-analyses and systematic reviews were included for synthesizing evidence. The proportion of articles which observed improvement with a reasonable amount of evidence was the highest at process $(69 \%)$, followed by health services $(63 \%)$, QOL (57\%), health outcomes $(51 \%)$, satisfaction $(50 \%)$, costs $(38 \%)$ and so on. As to mortality, statistically significant results were observed only in coronary heart disease. Important components in DM, such as a multidisciplinary approach, were identified.

Conclusion: The evidence synthesized shows considerable evidence in the effectiveness and efficiency of DM programs in process, health services, QOL and so on. The question is no longer whether DM programs work, but rather which type or component of DM programs works best and efficiently in the context of each healthcare system or country.
\end{abstract}

Keywords: disease management, effectiveness, efficiency, process, health services

\section{Introduction}

The growing burden of chronic diseases, such as coronary heart disease, diabetes mellitus, depression, asthma, cancer, and so on, has contributed to increasing healthcare costs in the past decades all over the world (WHO, 2005; Adeyl et al., 2007). The management of healthcare for persons with chronic diseases has advanced substantially in recent decades, yet these issues remain deficient. To improve systematically the quality and efficiency of healthcare for chronic diseases are critical problems for healthcare decision-making (Wagner et al., 2002).

The disease management (DM) approach is increasingly advocated as a means of improving effectiveness and efficiency of healthcare for chronic diseases (Hunter et al., 1997). DM generally refers to a systematic population-based approach emphasizing coordinated and comprehensive care along the continuum of disease and across the health care delivery system (Epstein et al., 1997; Ellrodt et al., 1997). DM programs are complex and have many components, which are a combination of patient education, provider use of practice guidelines, appropriate education, and supplies of drugs and ancillary services (Hunter et al., 1997).

DM appealed to healthcare decision maker keen to contain costs and improve health outcome. Initially, DM programs were mainly extension services offered by the US pharmaceutical companies, but evolved into disease-specific programs and more recently into comprehensive condition management programs (Walker et al., 2002; Shelton, 2002). Moreover, DM programs have evolved and been disseminated into other countries and organizations, such as the EU (Department of Health, 2002; Busse, 2004; Singh, 2008), Canada (Wong et al., 2004) and WHO (2002). 
Numerous studies have been carried out to evaluate the impact of DM programs. However, the quality of these studies has varied very widely and the effectiveness of DM programs has remained undetermined (Walker et al., 2002; Linden et al., 2005). Moreover, recent large randomized trials of Medicare-coordinated care demonstration for DM under a fee-for-service context in the US failed to demonstrate effectiveness or cost reduction (Peikes et al., 2009). Those results have evoked a lot of controversies on the value of DM programs in the US (Ayanian, 2009) and have led to a focus on alternative approaches such as medical home (Rosental, 2008), care coordination (Boult et al., 2010), and transitional care (Naylor et al., 2004). However, while firm evidence on effectiveness and /or efficiency for these approaches is still lacking, recent analyses of the method of Medicare demonstration projects suggested that well-targeted DM efforts can be cost-effective (Brown, 2009).

Therefore, to examine and summarize the existing evidence on effectiveness and efficiency of diverse DM programs, as well as DM's applicability to a healthcare system is extremely valuable to the formulation of future healthcare decision making and the exploration of possibilities for new approaches. The author has examined these issues before (Velasoc-Garrido et al., 2003), and indicated that most of the DM programs evaluated have been shown to improve the management of diseases, although there is insufficient evidence on mortality reduction, as the final outcome, and cost-effectiveness. Since then, numerous meta-analyses and systematic reviews of DM in several disease areas have been expanded and accumulated rapidly. This article critically evaluates and synthesizes the evidence on effectiveness and efficiency of DM programs from meta-analyses and/or systematic reviews available.

\section{Methods}

Since there is no consensus about the definition of disease management, we have done a systematic literature search for evidence from meta-analyses and/or systematic reviews relative to the effectiveness and efficiency of DM programs for chronic diseases, by using a broad definition of disease management with several key components (Hunter et al., 1997; Epstein et al., 1997; Ellrodt et al., 1997), as is mentioned before. The inclusion criteria for relevant articles were as follows: a reference to the definition of disease management, inclusion of more than one component of disease management programs, satisfaction for minimum requirement for meta-analyses or systematic reviews (e.g., explicit question and search strategy), and outcomes measures (e.g., patient outcomes or costs). As an exception, articles relative to the Chronic Care Model (Bodenheimer et al., 2002) were included, even if they did not refer to disease management. Articles with only specific and single intervention (e.g., self-management, case management, etc), or no outcome measure, and narrative reviews were excluded.

To identify articles as meta-analyses and/or systematic reviews of DM programs, we conducted systematic literature searches in several databases between January 1995 and May 2010. The former report confirmed that there was no relevant article before 1995. Firstly, as a preliminary search, we conducted a search in Medline with the following key words: 'disease management' and, 'meta-analysis' or 'systematic review'. Ninety-three articles were identified as meta-analyses or systematic reviews. Their contents were examined to construct a further literature search strategy and 8 key outcome items for data extraction: mortality, health outcomes, process, quality of life (QOL), satisfaction, knowledge or life-style change, health services, and costs.

Based on this result, the following databases were searched: Medline, EMBASE, SCI-EXPANDED, SSCI, A\&HCI, Cochrane Library (Cochran Reviews, DARE, HTA, NHS EED). We constructed a search strategy by using combinations of the following keywords: "disease management or disease management programs", "comprehensive multidisciplinary program", "case management or case management program", "care management or care management program", "chronic disease", "meta-analysis", and "systematic review".

Titles and abstracts of articles were reviewed for relevance according to the inclusion criteria by two reviewers, who are experts in health technology assessment with experience over 20 years, and, if potentially relevant, we retrieved the full-text article. The items of information were extracted and synthesized. The initial search strategy identified 2304 references. Independently, two researchers reviewed both all titles and abstracts simultaneously. After removing articles, which dealt with irrelevant topics, acute diseases, and primary studies, we accepted 102 articles for further screening as potentially eligible ones and reviewed their full texts. Twenty-eight articles met our inclusion criteria: 20 were meta-analyses (Gohler et al., 2006; Roccaforte et al., 2005; Wellan et al., 2005; Phillips et al., 2005; Gonseth et al., 2004; McAlister et al., 2001a, 2001b; Lemmens et al., 2009; Peytremann-Bridevaux et al., 2008; Adams et al., 2007; Taylor et al., 2005; Sin et al., 2003; Knight et al., 2005; Noris et al., 2002; Neumeyer-Gromen et al., 2004; Badamgarav et al., 2003a, 2003b; Tsai et al., 2005; Krause, 2005; Weingarten et al., 2002) and the remaining 8 were qualitative systematic reviews (Yu et al., 2006; Jerant et al., 2005; Ara, 2004; Maciejewski et al., 2009; Steuten et al., 2009; Niesink et al., 2007; Steuten et al., 2007; 
Ofman et al., 2004). Articles excluded had the following characteristics: narrow focus on self-management, case management, care management, or health promotion, insufficient search strategy, recommendation oriented, annotated bibliography and narrative reviews.

A preliminary review was done to decide key outcome items, which were relevant for evaluating disease management programs. The following 8 items were identified: mortality, health outcomes (e.g., morbidity, disability and function), process (e.g., compliance or adherence to guidelines), quality of life, satisfaction, knowledge or life-style, health services (e.g., hospitalization or admission), and costs. Data on 8 key outcome items were extracted by two researchers, independently. Discrepancies were resolved by consensus development between them.

The quality of meta-analyses and systematic reviews were explicitly assessed according to the guide developed by the Evidence-Based Medicine Working Group (Oxman et al., 2002). Two items (i.e., validity and contents of results) and their 7 sub-items among three items in this guide were used to assess the quality of these analyses and reviews. The item related to applicability was excluded, since this item mainly depended on the context of each user. The proportion of sub-items satisfied by each paper was more than $70 \%$, although the sub-item for precision of results was not applicable to qualitative reviews.

The data obtained were analyzed and presented according to the following items: the definition and components of DM, the effectiveness and efficiency of DM programs, the features of interventions in DM programs and economics of DM programs. This study was carried out between June 2010 and April 2011.

\section{Results}

\subsection{Definition and Components of Disease Management}

Table 1 shows the definitions of DM programs cited among all 28 articles evaluated. Although there was something similar among them, there existed no common definition of DM, and a considerable variation was observed, strictly speaking. While seven articles had their own definitions (Gohler et al., 2006; Whellan et al., 2005; Phillips et al., 2005; Maciejewski et al., 2009; Nori et al., 2002, Neumeyer-Gromen et al., 2004; Badamgarav et al., 2003a), four articles (Gonseth et al., 2004; Niesink et al., 2007; Weingarten et al., 2002; Ofman et al., 2004) adopted the definition of Weingarten (2002) and four articles (Lemmens et al., 2009; Steuten et al., 2009; 2007; Krause, 2005) adopted that of the Disease Management Association America (2003). Three articles (Jerant et al., 2005; Ara, 2004; Knight et al., 2005) referred to the same definition of Epstein (Epstein et al., 1996). Also, three articles (Yu et al., 2006; Peytremann-Bridevaux et al., 2008; Badamgarav et al., 2003b) adopted that of Ellrodt (1997) and two articles (McAlister et al., 2001b; Sin et al., 2003) that of Hunter (1997). One specific definition of the chronic care model was mentioned in three articles (Adams et al., 2007; Steuten et al., 2009; Tsai et al., 2005). This definition did not use the expression of DM, but what it specified could be classified as DM in a broad sense. On the other hand, there was no explicit statement about the definition in three articles (Roccaforte et al., 2005; McAlister et al., 2001a; Taylor et al., 2005).

Despite the diversity of the definition of DM, several key components were mentioned in the definitions of DM as follows: systematic, comprehensive, population-based, multi-components, coordinated healthcare, specific disease entity, continuous quality improvement, multidisciplinary, practice guidelines, patient and/or provider education, and so on (Table 1). As is shown in Table 2, in each article, several key words were used for searching relevant articles for meta-analyses or systematic reviews on DM as follows: disease management, case management, comprehensive health care, health service research, multidisciplinary care, guidelines, home care services, patient care planning, primary care nursing, and so on.

\subsection{Effectiveness and Efficiency of DM Programs}

a. Overall Studies

Table 2 shows the characteristics of DM programs, main results and conclusions among articles (i.e., 20 meta-analyses and 8 qualitative systematic reviews). Table 3 shows the summary of important outcomes in DM programs. Details of improvement in each article and in each item are shown in Table 2.

The item most frequently evaluated was health services (e.g., hospitalization, admission, etc) $(79 \%, 22 / 28)$, followed by QOL $(75 \%, 21 / 28)$, health outcomes (e.g., physiological and functional status, disability, etc) (57\%, $16 / 28)$, healthcare process (e.g., adherence to guidelines, screening frequency, etc) $(57 \%, 16 / 28)$, costs $(57 \%$, $16 / 28)$, mortality $(54 \%, 15 / 28)$. The proportion of articles evaluating knowledge or life-style change, and satisfaction was $36 \%(10 / 28)$ and $21 \%(6 / 28)$, respectively. 
The proportion of articles which observed improvement with considerable evidence (the symbol $\circ$ means meta-analysis and $\triangle$ means qualitative review) was the highest for process $(69 \%, 11 / 16)$, followed by health services $(63 \%, 14 / 22)$, QOL $(57 \%, 12 / 21)$, satisfaction $(50 \%, 3 / 6)$, knowledge or life-style $(30 \%, 5 / 16)$, health outcomes $(51 \%, 9 / 16)$, costs $(38 \%, 6 / 16)$ and mortality $(20 \%, 3 / 15)$. As to mortality, statistically significant results were observed only in the area of coronary heart disease (CHD).

If improvement with limited evidence (indicated by $\triangle$ ? for qualitative review) was included, this proportion increased, and ranged from $100 \%$ (satisfaction) to $20 \%$ (mortality). In particular, the proportion in satisfaction, QOL, health services, and knowledge or life-style increased respectively to $100 \%, 81 \%, 81 \%$ and $70 \%$. On the other hand, if improvement was limited only to results with statistically significance by meta-analysis (osymbol), the proportion decreased and ranged from $50 \%$ (health outcome) to $10 \%$ (knowledge or life-style).

\section{b. Coronary Heart Diseases}

Seven meta-analyses (Gohler et al., 2006; Roccaforte et al., 2005; Whellan et al., 2005; Phillips et al., 2005; Gonseth et al., 2004; McAlister et al., 2001a, 2001b) and 3 qualitative reviews (Yu et al., 2006; Jerant et al., 2005; Ara, 2004) evaluated DM programs for CHD, including hypertension and hyperlipidemia (Tables 2 and 3 ). In addition, 1 meta-analysis 49) evaluated DM programs for CHD among multiple diseases.

The proportion of articles which observed improvement with considerable evidence was the highest for health services $(80 \%, 8 / 10)$, followed by process $(67 \%, 4 / 6)$, satisfaction $(50 \%, 3 / 6)$, health outcomes $(50 \%, 1 / 2)$, knowledge or life-style $(50 \%, 1 / 2)$, QOL $(43 \%, 3 / 7)$, costs $(38 \%, 3 / 8)$ and mortality $(33 \%, 3 / 9)$. As to mortality, statistically significant results by meta-analyses were observed only recently (Gohler et al., 2006; Roccaforte et al., 2005). The item of satisfaction was not evaluated.

If improvement with limited evidence was included, the proportion in health outcome, knowledge or life-style, health services, QOL and process increased to $100 \%(2 / 2), 100 \%(2 / 2), 90 \%(9 / 10), 86 \%(6 / 7)$ and $83 \%(5 / 6)$, respectively.

\section{c. COPD}

Five meta-analyses (Lemmens et al., 2009; Peytremann-Bridevaux et al., 2008; Adams et al., 2007; Taylor et al., 2005; Sin et al., 2003) and four qualitative reviews (Maciejewski et al., 2009; Steuten et al., 2009; Niesink, 2007; Steuten et al., 2007) evaluated DM programs for COPD (Tables 2 and 3). In addition, 1 meta-analysis ${ }^{49}$ evaluated DM programs for COPD among multiple diseases.

The proportion of articles which observed improvement with considerable evidence was the highest for QOL $(78 \%, 7 / 9)$, followed by health services $(75 \%, 6 / 8)$, process $(40 \%, 2 / 5)$, knowledge or life-style $(33 \%, 2 / 6)$, costs $(33 \%, 1 / 3)$ and health outcomes $(29 \%, 2 / 7)$. Those for mortality and satisfaction were $0 \%(0 / 5)$ and $0 \%(0 / 2)$, respectively. If improvement with limited evidence was included, the proportion in satisfaction, health services, knowledge or life-style, costs increased to $100 \%(2 / 2), 88 \%(7 / 8), 67 \%(4 / 6)$, and $67 \%(2 / 3)$, respectively.

\section{d. Diabetes}

Two meta-analyses (Knight et al., 2005; Noris et al., 2002) evaluated DM programs for diabetes mellitus (Tables 2 and 3). In addition, 1 meta-analysis (Weingarten et al., 2002) evaluated DM programs for diabetes mellitus among multiple diseases.

The proportion of articles which observed improvement with considerable evidence was the highest for process $(100 \%, 3 / 3)$ and health outcomes $(100 \%, 2 / 2)$, followed by knowledge or life-style $(67 \%, 2 / 3)$. Those in QOL, satisfaction, health services and costs were $0 \%$. Mortality was not evaluated. If improvement with limited evidence was included, the proportion in knowledge or life-style, QOL, satisfaction and health services increased to $100 \%$.

\section{e. Depression}

Two meta-analyses (Neumeyer-Gromen et al., 2004; Badamgarav et al., 2003b) evaluated DM programs for depression (Tables 2 and 3). In addition, 1 meta-analysis (Weingarten et al., 2002) evaluated DM programs for depression among multiple diseases. The proportion of articles which observed improvement with considerable evidence was $100 \%$ in health outcomes (2/2), process (3/3), satisfaction (2/2) and knowledge or life-style (1/1), followed by QOL $(50 \%, 1 / 2)$ and costs $(50 \%, 1 / 2)$. That in health services was $0 \%(0 / 1)$. Mortality was not evaluated. 


\section{f. Rheumatoid Arthritis}

One meta-analysis (Badamgarav et al., 2003a) evaluated DM programs for rheumatoid arthritis (Tables 2 and 3). In addition, 1 meta-analysis (Weingarten et al., 2002) evaluated DM programs for rheumatoid arthritis among multiple diseases. Improvement was observed for health outcomes (1/1), process (1/1), and knowledge or life-style (1/1). Five items (i.e., mortality, QOL, satisfaction, health services and costs) were not evaluated.

g. Multiple Diseases

Three meta-analyses (Tsai et al., 2005; Krause, 2005; Weingarten et al., 2002) and 1 qualitative review (Ofman et al., 2004) evaluated DM programs on multiple diseases (Tables 2 and 3).

The proportion of articles which observed improvement with considerable evidence was $100 \%$ in process $(3 / 3)$, QOL (1/1), satisfaction (1/1) and knowledge or life-style (2/2), followed by health services $(50 \%, 1 / 2)$ and costs $(50 \%, 1 / 2)$. That in mortality and health services was $0 \%(0 / 1)$.

\subsection{Features of Interventions in DM Programs}

While the types of interventions in DM programs were summarized in Tables 2, the results related to specific interventions by meta-analyses and qualitative reviews are shown in Table 4. The proportion of articles which examined effect or impact of specific interventions in DM programs was 43\% (12/28).

Multidisciplinary team approaches (Gohler et al., 2006; Roccaforte et al., 2005; McAlister et al., 2001a) were the most frequently indicated intervention which were related to health outcomes (e.g., mortality or morbidity) and health services utilization (e.g., hospitalization). Also, multi-component programs (Lemmens et al., 2009; Adams et al., 2007; Tsai et al., 2005) were mostly shown or suggested to be effective in QOL, health services, and other items, in both usual DM and CCM programs.

Besides these interventions, other interventions were as follows: clinical follow-up by specialists (Whellan et al., 2005), home visit (Whellan et al., 2005), hospital discharge planning or post-discharge follow-up (Gohler et al., 2006; Phillips et al., 2005), counseling in hospital by allied health professionals (Steuten et al., 2009), and education or reminder for providers and patients (Weingarten et al., 2002).

On the other hand, while disease severity as a target of DM programs played an important role (Krause, 2005), high quality of studies (Roccaforte et al., 2005) and long term interventions (Roccaforte et al., 2005; Taylor et al., 2005; Badamgarav et al., 2003b) were important factors for evaluating effectiveness.

\subsection{Economics}

The economic evaluation of DM programs was reported in 16 articles (Tables 3 and 4). The proportion of articles with considerable evidence, indicating some form of favorable effects, was $38 \%(6 / 16)$. If articles with limited evidence were included, the proportion increased to $50 \%(8 / 16)$.

However, as is shown in Table 4, there were few comprehensive economic revaluations and their systematic reviews. While there was no, or very limited, information on costs in articles (McAlister et al., 2001a; Yu et al., 2006; Jerant et al., 2005; Ara, 2004; Steuten et al., 2007; Ofman et al., 2004). costs for interventions, rather than healthcare costs, were rarely or insufficiently described, even if costs were reported (Whellan et al., 2005; Adams et al., 2007; Steuten et al., 2009; Badamgarav et al., 2003b; Krause, 2005). Only one article (Neumeyer-Gromen et al., 2004) showed the cost-effectiveness/cost-utility ratios, as an economic summary measure, which varied from $\$ 9,051$ to $\$ 49,500$ per QALY.

\subsection{Study Design and Quality of Studies Reviewed}

The main types of study design of studies reviewed among the articles were randomized controlled trials (RCTs), controlled trials (CTs), cohort studies and before-after studies (Table 1). As is shown in Table 1, the proportion of articles, which included only RCTs (or experimental studies) and RCTs or CTs (or quasi-experimental studies) were $43 \%$ and $64 \%$, respectively. The former proportion varied from $100 \%$ to $19 \%$.

Table 4 shows information on the results of reviewing the quality of studies included in each article. The proportion of articles evaluating quality of studies was $61 \%$ (17/28). While the Jadad score (1996) was used in about one third of quality evaluations (Phillips et al., 2005; Gonseth et al., 2004; Peytremann-Bridevaux et al., 2008; Taylor et al., 2005; Taais et al., 2005; Ofman et al., 2004), other criteria such as the HTA Disease Management (Steuten et al., 2004), the Cochrane Collaboration Handbook (2006) and the evidence-based Guide to Community Preventive Services-method (Briss et al., 2000) were also used. The proportion of studies with high or good quality, according to the criteria used, varied widely form $20 \%$ to $80 \%$. 


\section{Discussion}

The synthesis of meta-analyses and systematic reviews on DM programs showed considerable evidence of their effectiveness on outcomes from healthcare outcomes, health process and health services, to knowledge, satisfaction, QOL and costs (Tables 2-4). Even if only meta-analyses were examined, similar results were obtained. However, as to mortality, evidence is very limited and inconclusive. Two recent meta-analyses (Gohler et al., 2006; Roccaforte et al., 2005) showed statistically significant mortality reduction. These results were mostly shared among subgroups of target diseases, such as CHD, COPD, diabetes and depression. The evidence of DM programs for rheumatoid arthritis is very limited.

An earlier synthesis report about DM programs (Velasoc-Garrido et al., 2003), based on only four systematic reviews available at that time, was unable to draw definitive conclusions about diverse outcomes of DM programs. Incorporating meta-analyses and systematic reviews over the past seven years, this synthesis could analyze the evidence on effectiveness and efficiency more deeply and comprehensively. However, the results of this study should be carefully examined for application to healthcare decision making.

First, DM programs vary widely in their structure, and are hard to describe with a single definition, since they usually contain many components. In this analysis, there existed no common definition of DM, and a considerable variation was observed (Tables 1 and 2). Also, diverse key words for searching literature on DM were differently mixed and used (Table 2). These different definitions and search strategies may lead to the inclusion of different studies and yield different results. While these results depend on the specific operational definition of DM, the effects of DM programs among different articles seem to be relatively similar (Table 3). However, there is an urgent need to develop a consensus on the more systematic or common concept and classification of DM programs, to allow for more reliable and valid analyses and comparisons.

Second, it is difficult to confirm the relative effectiveness and efficiency of the types, components or interventions of DM programs. In this synthesis, each article adopted its own components or interventions of DM programs (Tables 2 and 3). Most of these components and interventions were closely related to the components mentioned in the definitions of the Disease Management Association America (DMAA) (Disease Management Association America, 2003) and the Chronic Care Model (Bodenheimer et al., 2002).

These articles compared different components or their combinations, arbitrarily rather than systematically or comprehensively. The analysis of components indicated the statistically significant impact of the following components or interventions: multidisciplinary team interventions, clinical follow-up by a specialist, home visit or telephone follow-up, discharge planning and post-discharge follow-up, delivery system design, self-management, decision support, and so on (Tables 2-4).

This evidence obtained is closely related to the six components that appear to influence of effectiveness of DM after detailed analyses of Medicare demonstration projects after their failure (Brown, 2009). Also, new developments for chronic disease care, such as medical home (Rosenthal, 2008), care coordination (Boult et al., 2010) and transitional care (Naylor et al., 2004) shared a lot of components with DM programs in these articles reviewed, although the emphasis on components and their structure are very different among these approaches and DM programs. On the other hand, as to each component adopted by existing DM programs, there is evidence based on systematic reviews in self-management (Chodosh et al., 2005; Warsi et al., 2004; Blaiss, 2004, Monninkhof et al., 2003), care management (Windham et al., 2003), case management (Norris et al., 2002; Ferguson et al., 1998), multidisciplinary care (Philbin, 1999; McAlister et al., 2004) and integrated care (Owens et al., 2005).

Although these findings give an insight into the effective components of DM programs, the evaluation of components or interventions, as well as their combinations, is still in its infancy. It is not possible to draw conclusions about essential components or their ideal combinations for DM programs. A future challenge is the need to develop and implement more systematic and comprehensive analyses on components of DM programs.

Third, careful examination about the types of study design and their quality is the basis of evaluation of DM programs. In evaluating effectiveness of healthcare, RCT is recognized as a gold standard of a hierarchy of strength of evidence (Guyatt et al., 2002). The main types of study design for evaluating DM programs in this synthesis were randomized controlled trials (RCTs) and controlled trials (CTs), which comprised $43 \%$ to $64 \%$ of studies evaluating DM programs among the articles reviewed. The proportion of studies with high and good quality varied from $20 \%$ to $80 \%$.

These figures are not satisfactory to assure the validity of studies evaluated by the articles. However, they should be cautiously interpreted. The assessment of complex multi-component interventions and diverse measures of 
outcomes are methodological challenges unique to organizational or community interventions like DM programs. Although well-conducted RCTs provide the most reliable evidence, these are not always feasible for interventions in this situation. Also, RCTs may increase the internal validity, while decreasing the external validity. Corresponding to this challenge, the guide for allowing non-randomized controlled trials or observational studies is proposed by the Cochrane Effective Practice and Organization of Care Review Group (EPOC) (Cochrane Effective Practice and Organization of Care Review Group) and the Task Force on Community Preventive Services (Briss et al., 2000). Moreover, from the perspective of recent argument on comparative effectiveness study, practical trials or advanced observational studies would be more suitable for evaluation of DM programs (Dreyer et al., 2010).

The additional important issue related to study design is the unclear status of comparators. The studies in the reviews included in the articles used mostly compare DM programs with usual care. However, the organization and provision of usual care differs across and within healthcare systems. Therefore, precise components and interventions of usual care should be described and evaluated simultaneously. In evaluating DM programs, application of these criteria and consideration of comparators would increase feasibility and flexibility of evaluation and enable the evaluation to reflect the comprehensive view of effectiveness and efficiency of DM programs.

Forth, the most controversial outcomes in DM programs are mortality and cost-effectiveness. In this analysis, although the effectiveness of DM programs has been shown on health outcomes, process and services, only two meta-analyses demonstrated statistically significant mortality reduction in coronary heart diseases (Gohler et al., 2006; Roccaforte et al., 2005). In COPD, four meta-analyses failed to demonstrate significant decrease in mortality, although relative risks of mortality were less than 1 (Peytremann-Bridevaux et al., 2008; Adams et al., 2007; Taylor et al., 2005; Sin et al., 2003). There may be several explanations. Most analyses did not have a large enough sample size to detect a mortality reduction. Also, the follow-up period of the studies was relatively short. The average follow-up of most studies is less than 12 months. A large study population with long-term follow-up would be needed to evaluate actual impact of DM programs on mortality.

The number of meta-analyses and systematic reviews of economic evaluation of DM programs are relatively limited (Tables 3-4). The proportion of articles with favorable effects in costs or cost-effectiveness was $38 \%$ in this analysis. However, there were few articles which evaluated formally and comprehensively economic results. Economic evaluation is defined as the comparative analysis of alternative courses of action in terms of both their costs and consequences (Drummond et al., 2005). Since most studies of economic evaluation on DM programs focused only on costs, they are classified as partial evaluation (e.g., cost analysis), rather than full economic evaluation (e.g., cost-effective and cost-benefit analysis) (Drummond et al., 2005).

Furthermore, where costs were examined, undefined or very limited cost items, such as medical care costs, were evaluated in the articles. The implementation of DM programs requires substantial investments in development of a program, and additional human or organizational costs for implementing it (Kesteloot, 1999). A recent review (Goetzel et al., 2005) on return on investment (ROI) of DM programs reported a positive ROI in congestive heart failure and multiple diseases, but the range and detail of costs and benefits was unclear and limited under a financial point of view. Therefore, the cost savings or cost-effectiveness of DM programs still remained undetermined, and formal full economic evaluations are needed.

Finally, the generalizability and transferability of the findings in this synthesis has not been examined for applying them within and across countries. While DM programs have continued to evolve and mature over time and places, with failure and success, they have diffused from the US to other countries such as the UK (Departement of Health, 2002; Mason et al., 1999), Germany (Busse, 2004; Boseken, 2003), the Netherlands (Vrijhoef et al., 2001), Canada (Tsasis et al., 2008) and developing countries (WHO, 2002). In fact, many studies evaluating DM programs have been already carried out in other countries. For example, in a comprehensive systematic review (Roccaforte et al., 2005; Gonseth et al., 2004; Weingarten et al., 2002), while about a half of the studies came from the US, the other half came from the UK, the Netherlands, Sweden, Australia, Canada, Finland, Argentina, New Zealand, Italy, Israel, and so on. Therefore, much effort should be made towards examining generalizability or transferability of evidence about DM programs, according to the characteristics and context of the healthcare system in each country.

In summary, there is considerable evidence on the effectiveness and efficiency of DM programs, and several components or interventions in DM programs were suggested to be effective. However, further research is needed to examine which type or component of DM programs works best and efficiently. Also, new emerging approaches for care coordination of chronic diseases should be integrated or added to the DM approach. 


\section{References}

Adams, S. G., Smith, P. K., Allan, P. F., Anzueto, A., Pugh, J. A., \& Cornell, J. E. (2007). Systematic review of the chronic care model in chronic obstructive pulmonary disease prevention and management. Arch Intern Med, 167, 551-561. http://dx.doi.org/10.1001/archinte.167.6.551

Adeyl, O., Smith, O., \& Robles, S. (2007). Public policy and the challenge of chronic noncommunicable diseases. World Bank. Washington, D.C.

Ara, S. (2004). A literature review of cardiovascular disease management programs in managed care populations. J Manag Care Pharm, 10, 326-344.

Ayanian, J. Z. (2009). The elusive quest for quality and cost savings in the Medicare program. JAMA, 301, 668-669. http://dx.doi.org/10.1001/jama.2009.91

Badamgarav, E., Croft, J. R., Hohlbauch, A., Louie, J. S., O'Dell, J., Ofman, J. J., .. Katz, P. (2003a). Evidence-Based Medicine Working Groups in Rheumatology: Effects of disease management programs on functional status of patients with rheumatoid arthritis. Arthritis Rheumatism, 49, 377-387. http://dx.doi.org/10.1002/art.11120

Badamgarav, E., Weingarten, S. R., Henning, J. M., Knight, K., Hasselblad, V., Gano, A. Jr., \& Ofman, J. J. (2003b). Effectiveness of disease management programs in depression: a systematic review. Am J Psychiatry, 160, 2080-2090. http://dx.doi.org/10.1176/appi.ajp.160.12.2080

Blaiss, M. S. (2004). Asthma disease management: a critical analysis. Ann Allergy Asthma Immunol, 95, S10-S16. http://dx.doi.org/10.1016/S1081-1206(10)61004-6

Bodenheimer, T., Wagner, E. H., \& Grumbach, K. (2002). Improving primary care for patients with chronic illness. JAMA, 288, 1775-1779. http://dx.doi.org/10.1001/jama.288.14.1775

Boseken, W. H. (2003). Disease management programmes: reorganization of healthcare delivery in Germany. Nephrol Dial Transplant, 18, 1707-1710. http://dx.doi.org/10.1093/ndt/gfg262

Boult, C., \& Wieland, C. D. (2010). Comprehensive primary care for older patients with multiple chronic conditions. JAMA, 304, 1936-1943. http://dx.doi.org/10.1001/jama.2010.1623

Briss, P. A., Zaza, S., Pappaioanou, M., Fielding, J., Wright-De Agüero, L., Truman, B. I., ... Harris, J. R. (2000). The Task Force on Community Preventive Services: Developing an evidence-based guide to community preventive services, methods. Am J Prev Med, 18(1S), 35-43. http://dx.doi.org/10.1016/S0749-3797(99)00119-1

Brown, R. (2009). The promise of care coordination models that decrease hospitalization and improve outcomes for Medicare beneficiaries with chronic illness, A Report Commissioned by the National Coalition on Care Coordination, Mathematica Policy Research, Inc., Princeton.

Busse, R. (2004). Disease management programs in Germany's statutory health insurance system. Health Affairs, 23, 56-57. http://dx.doi.org/10.1377/hlthaff.23.3.56

Chodosh, J., Morton, S. C., Mojica, W., Maglione, M., Suttorp, M. J., Hilton, L., ... Shekelle, P. (2005). Meta-analysis: chronic disease self-management programs for older adults. Ann Intern Med, 143, 427-438.

Cochrane Collaboration. (2006). Cochrane handbook for systematic reviews of Interventions, 4.2.6, The Cochrane Library, issue 4 ed. Chichester, UK, Joh Wiley \& Sons, Ltd.

Cochrane Effective Practice and Organization of Care Review Group (EPOC). Study designs accepted in EPOC reviews, EPOC resources. (http://epoc.cochrane.org/epoc-resources)

Department of Health. (2002). Chronic disease management and self-care, National Service Frameworks, a practical aid to implementation in primary care. London.

Disease Management Association America. (2003). DMAA definition of disease management. (www.dmaa.org/defintion.html)

Dreyer, N. A., Tunis, S. R., Berger, M., Ollendorf, D., Mattox, P., \& Gliklich, R. (2010). Why observational studies should be among the tools used in comparative effectiveness research. Health Affairs (Millwood), 29, 1818-1825. http://dx.doi.org/10.1377/hlthaff.2010.0666

Drummond, M. F., Sculpher, M. J., Torrance, G. W., O'Brien, B. J., \& Stoddart, G. L. (2005). Methods for the economic evaluation of health care programmes, 3rd ed. Oxford Univ Press, NY. 
Ellrodt, G., Cook, D. J., Lee, J., Cho, M., Hunt, D., \& Weingarten, S. (1997). Evidence-based disease management. JAMA, 278, 1687-92. http://dx.doi.org/10.1001/jama.278.20.1687

Epstein, R. S., \& Sherwood, L. M. (1996). From outcomes research to disease management: a guide for perplexed. Ann Intern Med, 124, 832-837.

Epstein, R. S., \& McGlynn, M. G. (1997). Disease management, what is it? Dis Manage Health Outcomes, 1, 3-10. http://dx.doi.org/10.2165/00115677-199701010-00002

Ferguson, J. A., \& Weinberger, M. (1998). Case management program in primary care. J Gen Intern Med, 13, 123-126. http://dx.doi.org/10.1046/j.1525-1497.1998.00029.x

Goetzel, R. Z., Ozminkowski, R. C., Villagra, V. G., \& Duffy, J. (2005). Return on investment in disease management: a review. Health Care Finan Rev, 26(4), 1-19.

Gohler, A., Januzzi, J. L., Worrell, S. S., Osterziel, K. J., Gazelle, G. S., Dietz, R., \& Siebert, U. (2006). A systematic meta-analysis of the efficacy and heterogeneity of disease management programs in congestive heart failure. J Cardiac Failure, 12, 554-567. http://dx.doi.org/10.1016/j.cardfail.2006.03.003

Gonseth, J., Guallar-Castillon, P., Banegas, J. R., \& Rodríguez-Artalejo, F. (2004). The effectiveness of disease management programmes in reducing hospital re-admission in older patients with heart failure: a systematic review and meta-analysis of published reports. Eur Heart J, 25, 1570-1595. http://dx.doi.org/10.1016/j.ehj.2004.04.022

Guyatt, G., \& Rennie, D., eds. (2002). User's guides to the medical literature, essentials of evidence-based clinical practice. AMA press.

Hunter, D. J., \& Fairfield, G. (1997). Managed care: disease management. BMJ, 315, 50-53. http://dx.doi.org/10.1136/bmj.315.7099.50

Jadad, A. R., Moore, R. A., Carroll, D., Jenkinson, C., Reynolds, D. J., Gavaghan, D. J., \& McQuay, H. J. (1996). Assessing the quality of reports of randomized clinical trials: is blinding necessary? Controlled Clin Trials, 17, 1-12. http://dx.doi.org/10.1016/0197-2456(95)00134-4

Jerant, A. F., \& Nesbitt, T. S. (2005). Heart failure disease management incorporating telemedicine: a critical review. J Clin Outcome Management, 12, 207-217.

Kesteloot, K. (1999). Disease management: a new technology in need of critical assessment. Intern J Technol Assess Health Care, 15, 506-519.

Knight, K., Badamgarav, E., Henning, J. M., Hasselblad, V., Gano, A. D. Jr., Ofman, J. J., \& Weingarten, S. R. (2005). A systematic review of diabetes disease management program. Am J Manag Care, 11, 242-250.

Krause, D. S. (2005). Economic effectiveness of disease management programs: a meta-analysis. Dis Manag, 8 , 114-134. http://dx.doi.org/10.1089/dis.2005.8.114

Lemmens, K. M., Nieboer, A. P., \& Huijsman, R. (2009). A systematic review of integrated use of disease-management interventions in asthma and COPD. Resp Med, 103, 670-691. http://dx.doi.org/10.1016/j.rmed.2008.11.017

Linden, A., \& Roberts, N. (2005). A user's guide to the disease management literature: recommendations for reporting and assessing program outcomes. Am J Manag Care, 11, 113-120.

Maciejewski, M. L., Chen, S. Y., \& Au, D. H. (2009). Adult asthma disease management: an analysis of studies, approaches, outcomes, and methods. Resp Care, 54, 878-886. http://dx.doi.org/10.4187/002013209793800385

Mason, A., Towse, A., \& Drummond, M. (1999). Disease management, the NHS and the pharmaceutical industry. Office of Health Economics, London.

McAlister, F. A., Lawson, F. M. E., Teo, K. K., \& Armstrong, P. W. (2001a). A systematic review of randomized trials of disease management programmes in heart failure. Am $J$ Med, 110, 378-384. http://dx.doi.org/10.1016/S0002-9343(00)00743-9

McAlister, F. A., Lawson, F. M. E., Teo, K. K., \& Armstrong, P. W. (2001b). Randomized trials of secondary prevention programmes in coronay artery disease: systematic review. BMJ, 323, 957-962. http://dx.doi.org/10.1136/bmj.323.7319.957

McAlister, F. A., Stewart, S., Ferrua, S., \& McMurray, J. J. (2004). Multidisciplinary strategies for the management of heart failure patients at high risk for admission, a systematic review of randomized trials. $J$ 
Am Coll Cardiol, 44, 810-819. http://dx.doi.org/10.1016/j.jacc.2004.05.055

Monninkhof, E., van der Valk, P., van der Palen, J., van Herwaarden, C., Partridge, M. R., \& Zielhuis, G. (2003). Self-management education for patients with chronic obstructive pulmonary disease: a systematic review. Thorax, 58, 394-398. http://dx.doi.org/10.1136/thorax.58.5.394

Naylor, M. D., Brooten, D. A., Cambell, R. L., Maislin, G., McCauley, K. M., \& Schwartz, S. (2004). Transitional care of older adults hospitalized with heart failure: a randomized controlled trial. JAGS, 52, 675-684. http://dx.doi.org/10.1111/j.1532-5415.2004.52202.x

Neumeyer-Gromen, A., Lampert, T., Stark, K., \& Kallischnigg, G. (2004). Disease management programs for depression, a systematic review and meta-analysis of randomized controlled trial. Med Care, 42, 1211-1221. http://dx.doi.org/10.1097/00005650-200412000-00008

Niesink, A. (2007). Systematic review of the effects of chronic disease management on quality-of-life in people with chronic obstructive pulmonary disease. Resp Med, 101, 2233-2239. http://dx.doi.org/10.1016/j.rmed.2007.07.017

Noris, S. L., Nichols, P. J., Caspersen, G. J., Glasgow, R. E., Engelgau, M. M., Jack, L., .. McCulloch, D. (2002) The effectiveness of disease and case management for people with diabetes. A systematic review. Am J Prev Med, 22(4 Suppl), 15-38. http://dx.doi.org/10.1016/S0749-3797(02)00423-3

Ofman, J. J., Badamgarav, E., Henning, J. M., Knight, K., Gano, A. D. Jr., Levan, R. K., ... Weingarten, S. R. (2004). Does disease management improve clinical and economic outcomes in patients with chronic diseases? A systematic review. Am J Med, 117, 182-192. http://dx.doi.org/10.1016/j.amjmed.2004.03.018

Owens, M., Wollersheim, H., Hermens, R., Hulscher, M., \& Grol, R. (2005). Integrated care programmes for chronically ill patients: a review of systematic reviews. Int $J$ Quality Health Care, 17, 141-146. http://dx.doi.org/10.1093/intqhe/mzi016

Oxman, A., Guyatt, G., Cook, D., \& Montori, V. (2002). Summarizing the evidence, Guyatt G, Rennie D, eds: User's Guides to the medical literature, AMA Press, NY.

Peikes, D., Chen, A., \& Brown, R. (2009). Effects of care coordination on hospitalization, quality of care, and health care expenditures among Medicare beneficiaries, 15 randomized trials. JAMA, 301, 603-618. http://dx.doi.org/10.1001/jama.2009.126

Peytremann-Bridevaux, I., Staeger, P., Bridevaux, P. O., Ghali, W. A., \& Burnand, B. (2008). Effectiveness of chronic obstructive pulmonary disease-management programs: systematic review and meta-analysis. $\mathrm{Am} \mathrm{J}$ Med, 121, 433-443. http://dx.doi.org/10.1016/j.amjmed.2008.02.009

Philbin, E. F. (1999). Comprehensive multidisciplinary programs for the management of patients with congestive heart failure. J Gen Intern Med, 14, 130-135. http://dx.doi.org/10.1046/j.1525-1497.1999.00291.x

Phillips, C. O., Singa, R. M., Rubin, H. R., \& Jaarsma, T. (2005). Complexity of program and clinical outcomes of heart failure disease management incorporating specialist nurse-led heart failure clinics, a meta-regression analysis. Eur J Heart Failure, 7, 333-3441. http://dx.doi.org/10.1016/j.ejheart.2005.01.011

Roccaforte, R., Demers, C., Baldassarrre, F., Teo, K. K., \& Yusuf, S. (2005). Effectiveness of comprehensive disease management prgrammes in improving clinical outcomes in heart failure patients. Eur J Heart Fail, 7, 1133-1144. http://dx.doi.org/10.1016/j.ejheart.2005.08.005

Rosenthal, T. C. (2008). The medical home: growing evidence to support a new approach to primary care. $J \mathrm{Am}$ Board Fam Med, 21, 427-440. http://dx.doi.org/10.3122/jabfm.2008.05.070287

Shelton, P. S. (2002). Disease management programs. Dis Manage Health Outcomes, 10, 461-467. http://dx.doi.org/10.2165/00115677-200210080-00001

Sin, D. D., McAlister, F. A., Man, S. F. P., \& Anthonisen, N. R. (2003). Contemporary management of chronic obstructive pulmonary disease, scientific review. JAMA, 290, 2301-2312. http://dx.doi.org/10.1001/jama.290.17.2301

Singh, D. (2008). How can chronic disease management programes operate across care settings and providers? Policy brief. WHO Regional Office for Europe, Copenhagen.

Steuten, L. M., Vrijhoef, H. J., van Merode, G. G., Severens, J. L., \& Spreeuwenberg, C. I. (2004). The Health Technology Assessment-disease management instrument reliably measured methodologic quality of health technology assessment of disease management. $J$ Clin Epidemiol, 57, 881-888. 
http://dx.doi.org/10.1016/j.jclinepi.2004.01.017

Steuten, L., Lernmens, K., \& Vrijhoef, B. (2007). Health technology assessment of asthma disease management programs. Curr Opin Allergy Clin Immunol, 7, 242-248. http://dx.doi.org/10.1097/ACI.0b013e3280b10d7c

Steuten, L. M., Lemmens, K. M., Nieboer, A. P., \& Vrijhoef, H. J. (2009). Identifying potentially cost effective chronic care programs for people with COPD. Int J COPD, 4, 87-100.

Talyor, S. J. C., Bryar, R. M., Ramsay, J., Vrijhoef, H. J., Esmond, G., Wedzicha, J. A., \& Griffiths, C. J. (2005). Effectiveness of innovations in nurses led chronic disease management for patients with chronic obstructive pulmonary disease: systematic review of evidence. BMJ, 331, 485-491. http://dx.doi.org/10.1136/bmj.38512.664167.8F

Tsai, A. C., Morton, S. C., Mangione, C. M., \& Keeler, E. B. (2005). A meta-analysis of interventions to improve care for chronic illnesses. Am J Manag Care, 11, 478-488.

Tsasis, P., \& Bains, J. (2008). Management of complex chronic desiase: facing the challenges in the Canadian health-care system. Health Serv Manag Res, 21, 228-235. http://dx.doi.org/10.1258/hsmr.2008.008001

Velasoc-Garrido, M., Busse, R., \& Hisashige, A. (2003). Are disease management programms (DMPs) effective in improving quality of care for people with chronic conditions? WHO Europe, Copenhagen.

Vrijhoef, H. J. M., Spreeuwenberg, C., Eijkelberg, I. M. J. G., Wolffenbuttel, B. H. R., \& van Merode, G. G. (2001). Adoption of disease management model for diabetes in region of Maastricht. BMJ, 323, 983-9855. http://dx.doi.org/10.1136/bmj.323.7319.983

Wagner, E. H., \& Groves, T. (2002). Care for chronic diseases, the efficacy of coordinated and patient centered care is established, but now it the time to test its effectiveness. BMJ, 325, 913-914. http://dx.doi.org/10.1136/bmj.325.7370.913

Walker, D. R., McKinney, B. K., Cannon-Wagner, M., \& Vance, R. P. (2002). Evaluating disease management $\begin{array}{lllll}\text { programs. } & \text { Dis }\end{array}$ http://dx.doi.org/10.2165/00115677-200210100-00002

Warsi, A., Wang, P. S., LaValley, M. P., Avorn, J., \& Solomon, D. H. (2004). Self-management education programs in chronic disease, a systematic review and methodological critique of the literature. Arch Intern Med, 164, 1641-1649. http://dx.doi.org/10.1001/archinte.164.15.1641

Weingarten, S. R., Henning, J. M., Badamgarav, E., Knight, K., Hasselblad, V., Gano, A. Jr., \& Ofman, J. J. (2002). Interventions used in disease management programmes for patients with chronic illness-which one work? Meta-analysis of published reports. BMJ, 325, 925-932. http://dx.doi.org/10.1136/bmj.325.7370.925

Whellan, D. J., Hasselblad, V., Peterson, E., O'Connor, C. M., \& Schulman, K. A. (2005). Metaanalysis and review of heart failure disease management randomized controlled trials. Am Heart J, 149, 722-729. http://dx.doi.org/10.1016/j.ahj.2004.09.023

WHO. (2002). Innovative care for chronic conditions, building blocks for action. WHO, Geneva.

WHO. (2005). Preventing chronic diseases: a vital investment, WHO, Geneva.

Windham, B. G., Bennett, R. G., \& Gottlieb, S. (2003). Care management interventions for older patients with congestive heart failure. Am J Manage Care, 9, 451-459.

Wong. J., Gilbert, J., \& Kilburn, L. (2004). Seeking program sustainability in chronic disease management: the Ontario experience. Change Foundation.

Yu, D. S., Thompson, D. R., \& Lee, D. T. (2006). Disease management programmes for older people with heart failure: crucial characteristics which improve post-discharge outcomes. Eur Heart Journal, 27, 596-612. http://dx.doi.org/10.1093/eurheartj/ehi656 


\section{Appendix}

Table 1. Working definition of disease management (DM) and literature search

\begin{tabular}{ll}
\hline Article & Working definition \\
\hline CHD & \\
Meta-analysis & \\
Göhler & $\begin{array}{l}\text { DM programs focus on disease } \\
\text { education for the patient and } \\
\text { continuing support after hospital } \\
\text { discharge }\end{array}$
\end{tabular}

Roccaforte

2005

No explicit statement (only the words: comprehensive DM program)

DM is viewed as a means to Whellan increase the use of evidence-based 2005 therapies, improve patient education, and decrease resource usage.

DM protocols employed a variety of interventions, with or without Phillips components for hospital discharge 2005 planning and widely differing strategies for post-discharge care.

$\mathrm{DM}$ is an intervention designed to manage heart failure (HF) and

Gonseth reduce hospital re-admissions using 2004 a systematic approach to care and potentially employing multiple treatment modalities.

$\mathrm{DM}$ is a combination of patient

McAlister $2001 \mathrm{~b}$ education, provider use of practice guidelines, appropriate consultation, and supplies of drugs and ancillary services.

No explicit statement (only the

McAlister 2001a ords: comprehensive, multidisciplinary disease management)

\section{Qualitative review}

DM was operationally defined as a program that used multiple

Yu 2006 interventions in a systematic manner to manage HF across different health-care delivery system

DM is a systematic, population-based approach to

Jerant 2005 identify persons at risk, intervene with specific programs of care, and measure clinical and other outcomes
Databases: Medline (1966 2005)

Key words: congestive heart failure, disease management program, case management, early intervention, clinical protocol, patient care planning, nurse led clinics, home care services, etc

Databases: Medline, EMBASE, CINAHL, Cochrane (1980 2004) Key words: disease management, case management, comprehensive health care, health service research, health service costs, etc

Databases: Medline (1966 2003)

Key words: case management, comprehensive health care, health service research, home care services, clinical protocol, etc Databases: Medline, EMBASE, Cochrane (1966 2004)

Key words: multidisciplinary care, disease management, patient education, social work, case management, comprehensive discharge planning, etc

Databases: Medline, EMBASE, Cochrane (1966 2003)

Key words: guidelines, clinical pathways, protocols, algorism, care plans, quality improvement activities, patient support and education

Databases: Medline, EMBASE, CINAHL, SIGLE, Cochrane (1966 2000)

Key words: case management, comprehensive health care, disease management, health service researches, home care services, clinical protocol, etc

Databases: Medline, EMBASE, CINAHL, SIGLE, Cochrane (1966 1999)

Key words: case management, comprehensive health care, disease management, health service researches, home care services, clinical protocol, etc

Databases: Medline, EMBASE (1995 2005), Cochrane Controlled Trial Registry

Key words: DMP, cardiac failure or heart failure, readmission and rehospitalization

Databases: Medline, PsychINFO, CINAHL, Cochrane (1966 2004) Key words: disease management, case management, telemedicine, home care services, home nursing, home care services, hospitalization, etc
36 studies included (36 RCTs)

Inclusion criteria: RCT, endpoints (all-cause mortality and/or all-cause hospitalization), comparing DM with standard care, at least 3 months of follow-up

\section{3 studies included (RCTs)}

Inclusion criteria: out patient setting, comprehensive DM program, comparison with usual care, hospitalization rate, mortality

19 studies included (RCTs)

Inclusion criteria: randomized controlled trial

6 studies included (RCTs)

Inclusion criteria: randomized allocation of at least 100 patients, clearly defined protocol, the addition of specialist heart failure nurses, heart failure clinics

\section{4 studies included (27 RCTs, 27 CTs)}

Inclusion criteria: controlled studies assessing DM programs targeted, among others, at patients aged equal or more than 65 years with principal or secondary diagnosis (with specific exclusion criteria)

\section{2 studies included (RCTs)}

Inclusion criteria: randomized trial, more than 50 participants, impact of disease management on death, myocardial infarction, or admission rates.

11 studies included (RCTs) Inclusion criteria: randomized trial, effect of outpatient-based heart failure management programs on mortality or hospitalization rate, comprehensive DM system

21 studies included (21 RCTs)

Inclusion criteria: patients with HF, hospital admission and mortality, mean age more than 60 , detailed description of DM

33 studies included (RCTs)

Inclusion criteria: RCT, DM program, results for patients with HF separately from those other diseases, telemedicine element 


\begin{tabular}{llll}
\hline Article & Working definition & Databases and search strategy & Selected research and criteria \\
\hline \multirow{4}{*}{ Ara 2004 } & $\begin{array}{l}\text { DM is a systematic } \\
\text { population-based approach to } \\
\text { identify persons at risk, implement } \\
\text { detailed programs of care, measure } \\
\text { outcomes of interest, and achieve } \\
\text { continuous quality improvement. }\end{array}$ & $\begin{array}{l}\text { Cochrane, International } \\
\text { Pharmaceutical abstracts (1966 2002) } \\
\text { Key words: disease state management, } \\
\text { disease management, intervention, } \\
\text { quality improvement, managed care, } \\
\text { health maintenance organization, etc }\end{array}$ & $\begin{array}{l}\text { Inclusion criteria: implementation of } \\
\text { intervention, managed care settings, specific } \\
\text { disease states (congestive heart failure, } \\
\text { hypertension, hyperlipidemia-CAD) }\end{array}$ \\
\hline COPD \&
\end{tabular}

\section{Meta-analysis}

DM is a concept by which care delivery is coordinated through the Lemmens integration of several components 2009 across the entire delivery system and the application of tools specifically designed for population in question

DM, a multidisciplinary approach proposed to enhance the quality and cost-effectiveness of health care for

Peytremann chronic conditions, has been -Bridevaux defined as "an approach to patient 2008 care that emphasized coordinated, comprehensive care along the continuum of disease and across health care delivery system"

CCM identifies essential elements

Adams

2007 involving the community and health system and including self-management support, and clinical information systems.

Talyor No explicit statement (only the 2005 words: nurse led chronic DM)

DM is an approach to coordinate resources across the health care system with the aim of fostering community of care and increasing patients' knowledge and control over their chronic disease.

\section{Qualitative review}

$\operatorname{Sin} 2003$

DM programs are implemented to enable better disease control by

Maciejewski supporting the practitioner/patient 2009 relationship and a plan of care to prevent exacerbations and complications.

The aim of DM programs is to improve processes and outcomes of Steuten 2009 care whilst making a more efficient use of scarce health care resources, or even generate cost savings (e.g., DMAA or CCM)

Chronic DM programs are interventions designed to manage or

Niesink 2008
Databases: Medline and Cochrane Library (1995 2008)

Key words: disease management, disease state management, delivery of integrated health care, comprehensive health care, patient care planning, primary health care, etc

Databases: Medline, EMBASE, CINHAL, PsycINFO, Cochrane database (inception 2006)

Key words: COPD, intervention relating to disease management, study design

Databases: Medline (1966 2005), CINAHL (1982 2005), Cochrane (2005) Key words: disease management, case management, chronic disease, self-care, self-management, patient education, lung diseases, obstructive, etc

Databases: 16 English language databases (e.g., CINHAL, Cochrane, etc), 8 Dutch citation database (1980 2005) Key words: nursing care, community health nursing, patient discharge, outpatient clinic, home care service, community service, patient education, etc

Databases: Medline, Cochrane (1980 2002)

Key words: no specific indications about DM

Databases: Medline, EMBASE, CINAHL, PsychInfo, Cochrane database (1986 2008)

Key words: asthma, managed care programs, disease management, case management, patient care team, comprehensive health care Databases: Medline, Cochrane database (1995 2007)

Key words: disease management, disease state management, integrated delivery of health care, comprehensive health care, patient care planning, etc

Databases: Medline, EMBASE (1995 2006)

Key words: COPD, pulmonary emphysema, chronic bronchitis, quality of life, health status, health status indicator, RCT, etc
36 studies included (28 RCTs, 8 before-after studies with control)

Inclusion criteria: multiple interventions, patients aged over 16, control (usual care) or single intervention, objective measure of outcome, methodological quality

13 studies included ( 9 RCTs, 1 before-after study with control, 3 before-after studies without control)

Inclusion criteria: adult patients with COPD, fulfilling the operational definition of DM, not including inpatients only

32 studies included (26 RCTs, 5 CTs, 7

before-after studies with control)

Inclusion criteria: interventions with at least 1

CCM components, with a control or

comparison group (or outcome measured at two points), relevant outcomes

9 studies included (RCTs)

Inclusion criteria: clinical service intervention and package of care for managing COPD, nurse led, coordinated or delivered, randomized controlled trial

8 studies included (RCTs)

Inclusion criteria: disease management programs (any combination of patient education, enhanced follow-up, self-management session)

27 studies included (5 RCTs, 7 before-after studies with control, 12 before-after studies without control, 3 only after studies with control)

Exclusion criteria: children, patient education only, in-patient setting, opinion-based

17 studies included (14 RCTs, 2 CTs, 1 before-after study with control) Inclusion criteria: interventions more than two, studies with control or comparing group, relevant process or end outcomes evaluated

10 studies included (10 RCTs)

Inclusion criteria: RCT, clinical diagnosed COPD patients stable, outpatient integrated care, duration at least 8 weeks, measuring QOL 


\begin{tabular}{llll}
\hline Article & Working definition & Databases and search strategy & Selected research and criteria \\
\hline & $\begin{array}{l}\text { DM is a system of coordinated } \\
\text { healthcare interventions and } \\
\text { Steuten }\end{array}$ & $\begin{array}{l}\text { Databases: Medline, and Cochrane } \\
\text { database (2005 2006) }\end{array}$ & 8 studies included (3 RCTs, 4 before-after studies, \\
2007 & $\begin{array}{l}\text { Key words: six key components of } \\
\text { conditions in which self-care efforts } \\
\text { are significant. }\end{array}$ & $\begin{array}{l}\text { DM in addition to disease } \\
\text { management defined by DMMA, }\end{array}$ & Exclusion criteria: not compassing the whole \\
& & asthma, etc & continuum of care, single component of DM \\
\hline
\end{tabular}

\section{Diabetes \\ Meta-analysis}

$\begin{array}{ll}\text { Knight } & \text { DM is programs that use a } \\ 2005 & \text { systematic approach of care and } \\ \text { include more than } 1 \text { intervention } \\ \text { component. }\end{array}$

DM is an organized, proactive, multicomponent approach to

Noris 2001 healthcare delivery that involves all members of a population with a specific diseases entity.
Databases: Medline, HealthSTAR, Cochrane, (1987 2001)

Key words: disease state management, disease management, patient care team, patient care planning, primary nursing care, etc

Databases: Medline, ERIC, CINAHL, HealthSTAR (1966 2000)

Key words: case management, disease management, care model, shared care, primary health care, medical specialists, etc
24 studies included (19 RCTs, 5 CTs,) Inclusion criteria: adult patients, objective measurement of disease management, sufficient information to measure the effect of an intervention on at least 1 outcome, experimental or quasi-experimental study design 27 studies included (5 RCTs, 1 CT, 5 cohort studies, 15 before-after studies with control, 3 other studies)

Inclusion criteria: primary investigation, conducted in market economics, information on one or more outcomes of interest, all types of comparative studies

\section{Depression \\ Meta-analysis}

DM is a multidisciplinary, dynamic care model that strives for Neumeyer- continuous quality improvement. Gromen DM is a population-based care 2004 strategy and only assigned for highly prevalent chronic diseases.

$\mathrm{DM}$ is an intervention designed to manage or prevent a chronic Badamgarav condition by using a systematic 2003 b approach to care and potentially employing multiple treatment modalities.
Databases: Medline, PSYCLIT, PSYNDEX, EMBASE, Cochrane, BMJ database, etc (1966 2002) Key words: disease management program, depression management program, cost-effectiveness

Databases: Medline, HealthSTAR, Cochrane (1987 2001)

Key words: disease management, disease state management, patient care team, patient care planning, primary nursing care, case management, critical pathway, primary health care, etc
10 studies included (RCTs)

Inclusion criteria: complete DM programs with all components, randomized controlled study, adult patients above 18 years old

19 studies included (18 RCTs, 1 before-after study with control,)

Inclusion criteria: complete DM programs with all components, randomized controlled study, adult patients above 18 years old

\section{Rheumatoid arthritis}

\section{Meta-analysis}

DM is a multidisciplinary intervention to deliver by a team of

Badamgarav health care professionals, providing 2003a a systematic approach to care, and including a patient education component.
Databases: Medline, HealthSTAR, EMBASE, Cochrane (1966 2001)

Key words: disease management, patient care team, patient care planning, primary nursing care, case management, critical pathways, etc
11 studies included (8 RCTs, 3 CTs)

Inclusion criteria: target population, evaluation of a DM intervention, patients' functional status, RCT or quasi-experimental design

\section{Multiple disease \\ Meta-analysis}

The CCM is a primary care-based framework aimed at improving the care of patients with chronic illness. The model integrates a number of Tsai 2005 elements into a plausible package designed to foster more productive interactions between prepared, proactive teams and well-informed motivated patients.

$\mathrm{DM}$ is defined as a system of coordinated healthcare interventions and communications for

Krause 2005 populations with conditions in which patient self-care efforts are significant.
Databases: Medline, Cochrane for systematic reviews, and Medline for more recent individual studies (1993 2003)

Key words: 4 diseases (asthma, congestive heart failure, depression, diabetes), 6 elements of CCM (23 items)

Databases: Medline, DMMA's LitFinder (1995 2003)

Key words: disease management, economic, outcomes
112 randomized or non-randomized trial studies included ( 27 asthma, 21 congestive heart failure, 33 depression, 31 diabetes) Inclusion criteria: randomized or nonrandomized controlled studies, interventions tested (6 elements), outcomes of interest (clinical outcome, QOL, process of care)

67 studies included (34 experimental, 10 quasi-experimental, 23 before-after studies), (28 heart, 28 asthma, 11 diabetes) Inclusion criteria: chronic disease types (asthma, diabetes, heart disease), economic outcome measures (medial cost, hospital admission, clinic visit, emergency visit), DM interventions (self-management, nurse-management, team-management), study method 


\begin{tabular}{|c|c|c|c|}
\hline Article & Working definition & Databases and search strategy & Selected research and criteria \\
\hline \multirow{2}{*}{$\begin{array}{l}\text { Weingarten } \\
2002\end{array}$} & \multirow{2}{*}{$\begin{array}{l}\text { DM is an intervention designed to } \\
\text { manage or prevent a chronic } \\
\text { condition using a systematic } \\
\text { approach to care and potentially } \\
\text { employing multiple treatment } \\
\text { modalities. }\end{array}$} & \multirow{2}{*}{$\begin{array}{l}\text { Databases: Medline, HealthSTAR, } \\
\text { Cochrane (1987 2001) } \\
\text { Key words: disease state management, } \\
\text { disease management, patient care team, } \\
\text { patient care planning, primary nursing } \\
\text { care, case management, critical } \\
\text { pathway, primary health care, continuity } \\
\text { of patient care, guidelines, etc }\end{array}$} & $\begin{array}{l}102 \text { experimental or quasi-experimental studies } \\
\text { included ( } 26 \text { diabetes, } 25 \text { depression, } 10 \text { asthma, } \\
9 \text { congestive heart failure, } 9 \text { rheumatoid } \\
\text { arthritis, } 7 \text { hypertension, } 7 \text { COPD, etc ) }\end{array}$ \\
\hline & & & $\begin{array}{l}\text { Inclusion criteria: guideline or systematic } \\
\text { approach, experimental or quasi-experimental } \\
\text { study, estimation of at least one relevant } \\
\text { measure of program effects }\end{array}$ \\
\hline
\end{tabular}

\section{Qualitative review}

$\mathrm{DM}$ is an intervention designed to manage or prevent a chronic condition using a systematic

Ofman 2004
Databases: Medline, HealthSTAR, Cochrane (1987 2001)

Key words: disease state management, disease management, patient care team, patient care planning, primary nursing care, case management, critical pathway, primary health care, continuity of patient care, guidelines, etc
102 experimental or quasi-experimental studies included (22 diabetes, 25 depression, 9 heart failure, 9 rheumatoid arthritis, 8 asthma, 7 hypertension, 6 COPD, etc )

Inclusion criteria: pertain to chronic diseases, objective measurement of processes or outcomes, a systematic approach to care, experimental or quasi-experimental study, estimation of at least one relevant measure of program effects

DM: disease management, DMAA: Disease Management Association of America, CCM: chronic care model, RCT: randomized controlled trial, CT: controlled trial, HF: heart failure, COPD: chronic obstructive lung disease

Table 2. Characteristics of analysis and main results

\begin{tabular}{|c|c|c|c|}
\hline Article & $\begin{array}{l}\text { Diseases, interventions and } \\
\text { outcome measures }\end{array}$ & Main results & Conclusion \\
\hline \multicolumn{4}{|l|}{ CHD } \\
\hline \multicolumn{4}{|c|}{ Meta-analysis } \\
\hline $\begin{array}{l}\text { Göhler } \\
2006\end{array}$ & $\begin{array}{l}\text { Diseases: congestive heart failure } \\
\text { Interventions: multidisciplinary } \\
\text { approach, interventions centered on } \\
\text { specific health professionals } \\
\text { Outcomes: all-cause mortality, } \\
\text { all-cause hospitalization rate }\end{array}$ & $\begin{array}{l}\text { Mortality: Difference }=3 \% \text { (CI } 1 \sim 6 \%) \\
\text { Rehospitalization: Difference }=8 \%(5 \sim 11 \%) \\
\text { Factors for heterogeneity: severity of disease, } \\
\text { proportion of beta-blocker as baseline, } \\
\text { country, duration of follow-up, mode of post } \\
\text { discharge contact }\end{array}$ & $\begin{array}{l}\text { DM programs have the potential to } \\
\text { reduce morbidity and mortality for } \\
\text { patients with congestive HF. The } \\
\text { benefit of intervention depends on age, } \\
\text { severity of disease, guideline-based } \\
\text { treatment, and DM program modalities. }\end{array}$ \\
\hline $\begin{array}{l}\text { Roccaf } \\
\text { orte } \\
2005\end{array}$ & $\begin{array}{l}\text { Diseases: heart failure (HF) } \\
\text { Interventions: multidisciplinary } \\
\text { approach, interventions centered on } \\
\text { specific health professionals } \\
\text { Outcomes: mortality, } \\
\text { hospitalization rate }\end{array}$ & $\begin{array}{l}\text { Mortality reduction: } \mathrm{OR}=0.80(\mathrm{CI} 0.69 \sim 0.93) \\
\text { Hospitalization rates } \\
\text { for all-cause: } \mathrm{OR}=0.76(0.69 \sim 0.94) \\
\text { for HF } 0.58(0.50 \sim 0.67) \\
\text { ACE-1 therapy rate: } \mathrm{OR}=1.48(1.20 \sim 1.83) \\
\text { Different DM approaches were equally effective. }\end{array}$ & $\begin{array}{l}\text { DM program reduce mortality and } \\
\text { hospitalizations in HF patients. The } \\
\text { choice of a specific program depends } \\
\text { on local health services characteristics, } \\
\text { patient population, and resource } \\
\text { available. }\end{array}$ \\
\hline $\begin{array}{l}\text { Whellan } \\
2005\end{array}$ & $\begin{array}{l}\text { Diseases: HF } \\
\text { Interventions: clinic follow up by a } \\
\text { physician extender with cardiology } \\
\text { or primary care physician } \\
\text { supervision, home nursing follow } \\
\text { up, telephone follow up by a } \\
\text { physician extender } \\
\text { Outcomes: all-cause } \\
\text { hospitalization, QOL, mortality, cost }\end{array}$ & $\begin{array}{l}\text { All-cause hospitalization: significant } \\
\text { reduction with heterogeneity } \\
\text { QOL: more consistent improvement } \\
\text { Mortality: no difference in mortality with } \\
\text { some exceptions } \\
\text { Interventions using clinic follow-up by a } \\
\text { cardiologist, home visit, or telephone } \\
\text { follow-up significantly reduced all-cause } \\
\text { hospitalization. }\end{array}$ & $\begin{array}{l}\text { DM is an intervention that could } \\
\text { significantly decrease hospitalization } \\
\text { for patients with HF. Due to } \\
\text { differences in the types of strategies } \\
\text { and the variety of health care settings, } \\
\text { further studies of DM programs with } \\
\text { multiple participating centers are } \\
\text { required. }\end{array}$ \\
\hline $\begin{array}{l}\text { Phillips } \\
2005\end{array}$ & $\begin{array}{l}\text { Diseases: HF } \\
\text { Interventions: complex } \\
\text { components of DM, hospital } \\
\text { discharge planning } \\
\text { Outcomes: readmission, mortality, } \\
\text { and the combined endpoint of } \\
\text { mortality and hospitalization }\end{array}$ & $\begin{array}{l}\text { Readmission: } \mathrm{OR}=0.91 \text { (CI } 0.72 \sim 1.16) \\
\text { Mortality rate: } \mathrm{OR}=0.80(0.57 \sim 1.06) \\
\text { Combined endpoint: } 0.88(0.74 \sim 1.04) \\
\text { Suspected better outcomes for programs with } \\
\text { hospital discharge planning and } \\
\text { post-discharge follow-up (without statistical } \\
\text { comparison). }\end{array}$ & $\begin{array}{l}\text { DM with specialist nurse-led HF } \\
\text { clinics would be a promising strategy } \\
\text { or effective alternative whose benefit } \\
\text { may be optimized by programs with a } \\
\text { homogeneous structure and } \\
\text { components that are delivered with } \\
\text { consistency. }\end{array}$ \\
\hline $\begin{array}{l}\text { Gonseth } \\
2004\end{array}$ & $\begin{array}{l}\text { Diseases: HF } \\
\text { Interventions: types of DM } \\
\text { programs with home visits, } \\
\text { out-patient visits to a clinic, patient } \\
\text { longer follow-up } \\
\text { Outcomes: hospital readmission for } \\
\text { HF or other cardiovascular causes, } \\
\text { all-cause readmission, readmission } \\
\text { and mortality }\end{array}$ & $\begin{array}{l}\text { Readmission in } \mathrm{RCT} \text { for } \mathrm{HF} \text { or CVD : } \\
\mathrm{RR}=0.70 \text { (CI } 0.62 \sim 0.79) \text {, for all-cause: } \\
\mathrm{RR}=0.88(0.79 \sim 0.97) \\
\text { Combined event of readmission or death: } \\
\mathrm{RR}=0.82(0.72 \sim 0.94) \\
\text { The magnitude of DM program benefits } \\
\text { reported by non-randomized studies was more } \\
\text { than double that reported by randomized } \\
\text { studies. }\end{array}$ & $\begin{array}{l}\text { DM programs are effective at reducing } \\
\text { re-admissions among elderly patients } \\
\text { with HF. Their effectiveness is close to } \\
\text { that observed in clinical trials } \\
\text { evaluating drugs for HF. However, the } \\
\text { relative effectiveness of types of } \\
\text { healthcare delivery within the DM } \\
\text { program is not known. }\end{array}$ \\
\hline
\end{tabular}




\begin{tabular}{|c|c|c|c|}
\hline Article & $\begin{array}{l}\text { Diseases, interventions and } \\
\text { outcome measures }\end{array}$ & Main results & Conclusion \\
\hline $\begin{array}{l}\text { McAlister } \\
2001 b\end{array}$ & $\begin{array}{l}\text { Diseases: coronary heart disease } \\
\text { Interventions: multidisciplinary } \\
\text { DM program } \\
\text { Outcomes: reinfarction, all causes } \\
\text { mortality, admission to hospital, } \\
\text { process of care, QOL, costs }\end{array}$ & $\begin{array}{l}\text { Prescription of efficacious drugs: } \mathrm{RR}=2.14(\mathrm{CI} \\
1.92 \sim 2.38) \\
\text { Improvement of risk factor profiles: significant } \\
\text { improvement (moderate rage) } \\
\text { All cause mortality: } \mathrm{RR}=0.91(0.79 \sim 1.04) \\
\text { Recurrent myocardial infarction: } \mathrm{RR}=0.94 \\
(0.80 \sim 1.10) \text { Admission: } 0.84(0.76 \sim 0.94) \\
\text { QOL or functional status: better outcomes in } 3 \text { studies } \\
\text { Costs: savings in } 2 \text { studies }\end{array}$ & $\begin{array}{l}\text { DM programs improve process of care, } \\
\text { reduce admissions to hospitals and } \\
\text { enhance quality of life or functional } \\
\text { status in patients. The programs, } \\
\text { impact on survival and recurrent } \\
\text { infarctions, their cost-effectiveness, } \\
\text { and mix of components remain } \\
\text { uncertain. }\end{array}$ \\
\hline McAlister & $\begin{array}{l}\text { Diseases: HF } \\
\text { Interventions: comprehensive, } \\
\text { multidisciplinary DM program } \\
\text { Outcomes: hospitalization rate, all } \\
\text { cause mortality, medication, QOL, } \\
\text { costs }\end{array}$ & $\begin{array}{l}\text { Cost: saving in } 7 \text { of } 8 \text { trials reporting costs } \\
\text { reported Prescribing: beneficial effects } \\
\text { Hospitalization rate: } R R=0.87 \text { (CI } 0.79 \sim 0.96) \\
\text { All cause mortality: } R R=0.94(0.75 \sim 1.19) \\
\text { Specialized follow-up by a multidisciplinary } \\
\text { team led a significant reduction in } \\
\text { hospitalization, while telephone contact failed } \\
\text { to find any benefits. }\end{array}$ & $\begin{array}{l}\text { DM programs for the care of } \mathrm{HF} \\
\text { involving specialized follow up by a } \\
\text { multidisciplinary team reduce } \\
\text { hospitalization and appear to be cost } \\
\text { saving. Data on mortality are } \\
\text { inconclusive. Further studies are } \\
\text { needed to establish the incremental } \\
\text { benefits of the different elements of } \\
\text { DM programs. }\end{array}$ \\
\hline \multicolumn{4}{|c|}{ Qualitative review } \\
\hline $\begin{array}{l}\mathrm{Yu} \\
2006\end{array}$ & $\begin{array}{l}\text { Diseases: HF } \\
\text { Interventions: Education, } \\
\text { counseling, self-care support, } \\
\text { optimized medication, early } \\
\text { attention to clinical deterioration, } \\
\text { vigilant follow-up } \\
\text { Outcomes: hospital readmission, } \\
\text { mortality, combined events, QOL, } \\
\text { costs }\end{array}$ & $\begin{array}{l}\text { Significant effects (follow-up more than } 3 \\
\text { months): hospital readmission } 53 \%(10 / 19) \text {, } \\
\text { mortality } 3 \%(3 / 13) \text {, combined event } 62 \%(8 / 13) \text {, } \\
\text { QOL } 50 \%(4 / 8) \text {, cost reduction } 88 \%(7 / 8) \\
\text { Suggested factors for effective DM program (not } \\
\text { statistically significant): case management, } \\
\text { multi-disciplinary team, counseling by allied } \\
\text { health, optimized medical therapy, exercise } \\
\text { counseling, home visit }\end{array}$ & $\begin{array}{l}\text { This study defines precisely the } \\
\text { characteristics of the care team and the } \\
\text { organization content and delivery } \\
\text { method of the DM program which are } \\
\text { crucial to enhance the discharge } \\
\text { outcomes of older people with HF.. }\end{array}$ \\
\hline $\begin{array}{l}\text { Jerant } \\
2005\end{array}$ & $\begin{array}{l}\text { Diseases: HF } \\
\text { Interventions: HFDM } \\
\text { incorporating telemedicine, } 4 \text { types } \\
\text { of interventions } \\
\text { Outcomes: hospitalization, } \\
\text { emergency visit, mortality, QOL, } \\
\text { costs }\end{array}$ & $\begin{array}{l}\text { Hospitalizations and emergency visits: } \\
\text { significant reduction } \\
\text { Mortality, costs and QOL: varied among fewer } \\
\text { studies which examined them } \\
\text { There was no significant improvement in any } \\
\text { outcomes among less severe disease and /or in } \\
\text { health systems with preexisting proactive } \\
\text { approach. }\end{array}$ & $\begin{array}{l}\text { HFDM programs incorporating } \\
\text { telemedicine can reduce acute care } \\
\text { utilization by severely affected } \\
\text { patients, but their impact on other } \\
\text { outcomes is unproven. Less } \\
\text { symptomatic patients and those cared } \\
\text { for in well-organized health systems do } \\
\text { not appear to benefit from HFDM. }\end{array}$ \\
\hline $\begin{array}{l}\text { Ara } \\
2004\end{array}$ & $\begin{array}{l}\text { Diseases: cardiovascular disease } \\
\text { (congestive heart failure, } \\
\text { hypertension, hyperlipidemia } \\
\text { and/or coronary artery disease) } \\
\text { Interventions: multiple health care } \\
\text { professionals, patient and physician } \\
\text { education, intensive drug therapy, } \\
\text { lifestyle modification, close patient } \\
\text { monitoring } \\
\text { Outcomes: not specified }\end{array}$ & $\begin{array}{l}\text { A variety of interventions demonstrate some } \\
\text { effectiveness in improving to the } 3 \text { disease } \\
\text { states. While all } 5 \text { studies for CHF appeared to } \\
\text { be successful, } 3 \text { studies among } 9 \text { studies of } \\
\text { hypertension and } 6 \text { studies of } \\
\text { heperlipidemia-CAD were unsuccessful. A few } \\
\text { studies employed a fully experimental design } \\
\text { and posed significant limitations. }\end{array}$ & $\begin{array}{l}\text { A number of cardiovascular DM } \\
\text { strategies reported promising results. } \\
\text { Many of the multidisciplinary CH DM } \\
\text { programs were more complex than } \\
\text { were those for hypertension and } \\
\text { hyperlipidemia-CAD, due to the nature } \\
\text { and severity of the disease. }\end{array}$ \\
\hline
\end{tabular}

\section{COPD and asthma \\ Meta-analysis}

Diseases: asthma, COPD

Interventions: patient education, professional education, expansion

Lemmens or revision of professional roles,

2009 and/or case management

Outcomes: QOL, hospital

admission, healthcare utilization,

satisfaction, emergency visit

\section{Diseases: COPD}

Interventions: 2 or more

components (e.g., physical exercise, self-management, structured

Peytremann follow-up), 2 or more health care -Bridevaux professionals involved in patient 2008 care and patient education Outcomes: all-cause mortality, lung function, exercise capacity, QOL, acute exacerbations, health care use, etc
QOL score: difference $=-4.59(\mathrm{CI}-8.34 \sim-0.83)$

Hospital admission: $\mathrm{OR}=0.58(0.40 \sim 0.83)$

Emergency department visit: difference $=-4.59$

(CI -8.34 -0.83)

Process and knowledge: improvement in most studies

Lung function: no improvement

Healthcare utilization and satisfaction: ambiguous

Exercise capacity: Difference $=32.2(\mathrm{CI}$

\subsection{3)}

Mortality: OR $=0.85$ (CI $0.54 \sim 1.36$ )

Significant effects: Lung function $14 \%(1 / 7)$, QOL 73\% (8/11), symptoms 43\% (3/7), health care use $70 \%(7 / 10)$
DM programs in asthma and COPD shows improvement in QOL and reduction in hospitalization in multiple interventions. No effects on emergency department visits were found. Improvement in process was found in most studies. There was not consistent improvement in outcome indicators.

COPD DM programs modestly improved exercise capacity, health-related QOL, and hospital admission, but not mortality. 


\begin{tabular}{|c|c|c|c|}
\hline Article & $\begin{array}{l}\text { Diseases, interventions and } \\
\text { outcome measures }\end{array}$ & Main results & Conclusion \\
\hline $\begin{array}{l}\text { Adams } \\
2007\end{array}$ & $\begin{array}{l}\text { Diseases: COPD } \\
\text { Interventions: self-management, } \\
\text { delivery system design, decision } \\
\text { support, clinical information } \\
\text { system }\end{array}$ & $\begin{array}{l}\text { Hospitalization: } \mathrm{RR}=0.79(0.66 \sim 0.94) \\
\text { Emergency department visit: } \mathrm{RR}=0.58 \text { (CI } \\
0.42 \sim 0.79) \\
\text { Mortality: } \mathrm{RR}=0.58 \text { (CI } 0.26 \sim 1.29) \\
\text { Significant improvement: knowledge } 56 \% \\
(5 / 9), \mathrm{QOL} 20 \%(2 / 10), \text { length of hospital stay } \\
\text { in } 7 \text { studies } \\
\text { Cost reduction: } 11 \% \text { to } 70 \% \text { in } 10 \text { studies } \\
\text { Dyspnea, lung function,: no clinically } \\
\text { significant improvement }\end{array}$ & $\begin{array}{l}\text { Pooled data, evaluating the efficacy of } \\
\text { CCM components in COPD, } \\
\text { demonstrated that patients with COPD } \\
\text { who received interventions with } 2 \text { or } \\
\text { more CCM components had lower } \\
\text { rates of hospitalizations and } \\
\text { emergency/unscheduled visits and a } \\
\text { shorter length of stay compared with } \\
\text { control groups. }\end{array}$ \\
\hline $\begin{array}{l}\text { Talyor } \\
2005\end{array}$ & $\begin{array}{l}\text { Diseases: COPD } \\
\text { Interventions: nurse led chronic } \\
\text { DM, brief interventions, long term } \\
\text { or intensive interventions } \\
\text { Outcomes: survival, healthcare } \\
\text { utilization, ADL, QOL of patients } \\
\text { and carers }\end{array}$ & $\begin{array}{l}\text { Mortality: OR=0.85 (CI } 0.58 \sim 1.26) \\
\text { Emergency attendance, knowledge: possible } \\
\text { improvement } \\
\text { Patients' QOL, psychological wellbeing, } \\
\text { disability, pulmonary function, symptoms: no } \\
\text { difference detected }\end{array}$ & $\begin{array}{l}\text { There is little evidence to date to } \\
\text { support the widespread implementation } \\
\text { of nurse led management interventions } \\
\text { for COPD, but the data are too spare to } \\
\text { exclude any clinical relevant benefit or } \\
\text { harm arising from such interventions. }\end{array}$ \\
\hline $\begin{array}{l}\text { Sin } \\
2003\end{array}$ & $\begin{array}{l}\text { Diseases: COPD } \\
\text { Interventions: DM program, patient } \\
\text { education, enhanced follow-up } \\
\text { Outcomes: mortality, } \\
\text { hospitalization rate, QOL }\end{array}$ & $\begin{array}{l}\text { Mortality: } \mathrm{RR}=0.63(\mathrm{CI} 0.38 \sim 1.04) \\
\text { Hospitalization: } \mathrm{RR}=0.86(0.68 \sim 1.08) \\
\text { SGRQ score: }-2.5(14.8 \sim-0.1)\end{array}$ & $\begin{array}{l}\text { DM programs appear to improve } \\
\text { health status of patients, but may not } \\
\text { meaningfully impact on hospitalization } \\
\text { and mortality. However, this finding } \\
\text { may reflect differences in the core of } \\
\text { DM strategies across various studies. }\end{array}$ \\
\hline \multicolumn{4}{|c|}{ Qualitative review } \\
\hline $\begin{array}{l}\text { Maciej } \\
\text { ewski } \\
2009\end{array}$ & $\begin{array}{l}\text { Diseases: asthma } \\
\text { Interventions: patients and/or } \\
\text { providers education, assessment and } \\
\text { monitoring of patients, } \\
\text { non-physician providers involvement } \\
\text { Outcomes: health outcome, process, } \\
\text { hospitalization, } \\
\text { emergency-department visits, etc }\end{array}$ & $\begin{array}{l}\text { Statistically significant effects: clinical } \\
\text { outcomes (e.g., symptoms) 55\% (16/29), } \\
\text { medications } 57 \%(16 / 28) \text {, process (e.g., } \\
\text { inhaler technique) } 55 \%(16 / 30) \text {, economic } \\
\text { outcomes (e.g., hospitalization) } 58 \%(45 / 77) \text {, } \\
\text { patient-reported outcomes (e.g., quality of } \\
\text { life) } 47 \%(22 / 47)\end{array}$ & $\begin{array}{l}\text { Few well-designed studies with } \\
\text { rigorous statistical evaluation have } \\
\text { been conducted to evaluate DM } \\
\text { interventions for adults with asthma. } \\
\text { Current evidence is insufficient to } \\
\text { recommend any particular DM model } \\
\text { or interventions. }\end{array}$ \\
\hline $\begin{array}{l}\text { Steuten } \\
2009\end{array}$ & $\begin{array}{l}\text { Diseases: COPD } \\
\text { Interventions: self-management, } \\
\text { delivery system design, decision } \\
\text { support, clinical information systems }\end{array}$ & $\begin{array}{l}\text { Statistically significant effects: } \\
\text { disease-specific knowledge } 80 \%(4 / 5) \text {, QOL } \\
53 \%(8 / 15) \text {, decrease in health care utilization } \\
50 \%(7 / 15) \\
\text { Symptoms and function: equivalent } \\
\text { Coordination of care: mixed } \\
\text { Total costs:: no significant change }\end{array}$ & $\begin{array}{l}\text { Identifying cost effective } \\
\text { multi-components COPD programs } \\
\text { remains a challenges due to scarce } \\
\text { methodologically sound studies that } \\
\text { demonstrate significant improvements } \\
\text { on process, intermediate and end } \\
\text { results of care. }\end{array}$ \\
\hline $\begin{array}{l}\text { Niesink } \\
2008\end{array}$ & $\begin{array}{l}\text { Diseases: COPD } \\
\text { Interventions: multidisciplinary care } \\
\text { team, clinical pathway, case } \\
\text { management, self-management or } \\
\text { patient education }\end{array}$ & $\begin{array}{l}\text { Statistically significant improvement: QOL } \\
50 \%(5 / 10) \\
\text { Clinically relevant improvement: QOL } 70 \% \\
\text { ( } 7 / 10) \text { in intervention groups, } 40 \%(4 / 10) \text { in } \\
\text { control groups }\end{array}$ & $\begin{array}{l}\text { All chronic DM projects for people } \\
\text { with COPD involving primary care } \\
\text { improve quality of life. In most of the } \\
\text { studies, aspects of chronic DM were } \\
\text { applied to a limited extent. Quality of } \\
\text { RCTs was not optimal. }\end{array}$ \\
\hline $\begin{array}{l}\text { Steuten } \\
2007\end{array}$ & $\begin{array}{l}\text { Diseases: asthma } \\
\text { Interventions: educational (e.g. } \\
\text { self-management, or disease-specific } \\
\text { knowledge), professional (e.g., } \\
\text { changing performance or adherence } \\
\text { to guidelines), organizational (e.g., } \\
\text { improving the continuity of care) } \\
\text { interventions }\end{array}$ & $\begin{array}{l}\text { Statistically significant effect: hospitalization } \\
\text { or exacerbations } 71 \%(5 / 7) \text {, total costs }(1 / 1) \text {, } \\
\text { patient satisfaction }(1 / 1) \\
\text { Educational related process: mixed } \\
\text { Symptoms or lung function: no significant } \\
\text { change } \\
\text { QOL: no significant change }(0 / 3) \\
\text { Organizational effect: mixed }\end{array}$ & $\begin{array}{l}\text { There is accumulating circumstantial } \\
\text { evidence that DM programs reduce } \\
\text { resource utilization. But, the } \\
\text { generalizability of results remains } \\
\text { uncertain. }\end{array}$ \\
\hline
\end{tabular}

Diabetes
Meta-analysis
$\quad$ Diseases: diabetes mellitus

Interventions: interventions of

Knight systematic approach

2005 Outcomes: glycated hemoglobin, serum lipids, systolic blood pressure, hospital admission, screening for retinopathy, etc

Diseases: diabetes mellitus Interventions: DM and case

Noris management

2001 Outcomes: glycemic level, lipid level, BMI, QOL, knowledge, satisfaction, utilization, monitoring and screening
Hospitalization: $\mathrm{RR}=0.79(0.66 \sim 0.94)$

Emergency department visit: $\mathrm{RR}=0.58(\mathrm{Cl}$

Significant improvement: knowledge 56\%

(5/9), QOL $20 \%(2 / 10)$, length of hospital stay

studies

significant improvement

Mortality: $\mathrm{OR}=0.85$ (CI 0.58 1.26)

Emergency attendance, knowledge: possible disability, pulmonary function, symptoms: no

Mortality: $\mathrm{RR}=0.63(\mathrm{CI} 0.38 \sim 1.04)$

Hospitalization: $\mathrm{RR}=0.86(0.68 \sim 1.08)$

GRQ score: -2.5 (14.8 -0.1)

Statistically significant effects: clinical outcomes (e.g., symptoms) 55\% (16/29), ich echnique) $55 \%$ (16/30), economic patient-reported outcomes (e.g., quality of

Statistically significant effects:

disease-specific knowledge 80\% (4/5), QOL

(8)

Symptoms and function: equivalen

Coordination of care: mixed

Statistically significant improvement: QOL

$50 \%(5 / 10)$ control groups

Statistically significant effect: hospitalization pexienbations $71 \%(5 / 7)$

Educational related process: mixed

Symptoms or lung function: no significant

Organizational effect: mixed
Pooled data, evaluating the efficacy of CCM components in COPD, stay compared with There is little evidence to date to support the widespread implementation exclude any clinical relevant benefit or

health status of patients, but may not meaningfully impact on hospitalization may reflect differences in the core of

Few well-designed studies with rigorous statistical evaluation have Current evidence is insufficient to recommend any particular DM model or interventions. remains a challenges due to scarce methodologically sound studies that on process, intermediate and end results of care. studies, aspects of chronic DM were applied to a limited extent. Quality of

There is accumulating circumstantial Thidence that DM programs reduce generalizability of results remains uncertain.
Glycated hemoglobin control: - 0.49 (CI -0.56 $-0.41)$

Monitoring glycemic level: significant increase Screening for retinopathy: significant increase Foot screening and referral: improvement Foot care: significant decrease

Screening for nephropathy: inconclusive

Glycemic level: $-0.5 \%$ (CI -1.35 - 0.1 )

Monitoring, screening: significant improvement

Annual examination $7.7 \%$ (2.7 45.0)

Self-monitoring, QOL: significant improvement

Lipid level, blood pressure, cost: inconclusive
Diabetes DM programs can improve glycemic control to a model extent and can increase screening for retinopathy and foot complications.

This evidence for DM is applicable to adults with diabetes in managed care organization and community clinics in the US and Europe. Case management is effective both when delivered in conjunction with DM and when delivered with one or more additional educational, reminder or support intervention 


\begin{tabular}{|c|c|c|c|}
\hline Article & $\begin{array}{l}\text { Diseases, interventions and outcome } \\
\text { measures }\end{array}$ & \multicolumn{2}{|c|}{ Conclusion } \\
\hline \multicolumn{4}{|c|}{ Depression } \\
\hline \multicolumn{4}{|c|}{ Meta-analysis } \\
\hline $\begin{array}{l}\text { Neumey } \\
\text { er-Grom } \\
\text { en } 2004\end{array}$ & $\begin{array}{l}\text { Diseases: depression } \\
\text { Interventions: complete DM program } \\
\text { (evidence-based practice guidelines, } \\
\text { self-management education, etc) } \\
\text { Outcomes: depression severity, QOL, } \\
\text { employ status, satisfaction, adherence } \\
\text { to treatment regimen, } \\
\text { cost-effectiveness ratio }\end{array}$ & $\begin{array}{l}\text { Depression severity: } \mathrm{RR}=0.75 \text { (CI } 0.70 \sim 0.81) \\
\text { Adherence to medication: } \mathrm{RR}=0.59(0.46 \sim 0.75) \\
\text { Overall appropriate care: } \mathrm{RR}=0.77(0.70 \sim 0.85) \\
\text { CU ratio: } \$ 9,051 \text { - } \$ 49,500 \text { per } \mathrm{QALY} \\
\text { Patient satisfaction: } \mathrm{RR}=0.57(0.37 \sim 0.87) \\
\text { QOL: insufficient data available } \\
\text { Employment: significant holding in } 1 \text { study }\end{array}$ & $\begin{array}{l}\text { DM program significantly } \\
\text { enhance the quality of care } \\
\text { for depression. Costs are } \\
\text { within the range of other } \\
\text { widely accepted public health } \\
\text { improvement. }\end{array}$ \\
\hline $\begin{array}{l}\text { Badamg } \\
\text { arav } \\
2003 b\end{array}$ & $\begin{array}{l}\text { Diseases: depression } \\
\text { Interventions: multimodal DM program } \\
\text { Outcomes: depression symptom, } \\
\text { physical functioning, social and health } \\
\text { status, satisfaction, healthcare } \\
\text { utilization, hospitalization, cost, etc } \\
\end{array}$ & $\begin{array}{l}\text { Depression symptom: } \mathrm{ES}=0.33 \text { (CI } 0.16 \sim 0.49) \\
\text { Patient satisfaction: } \mathrm{ES}=0.51(0.33 \sim 0.68) \\
\text { Detection of derpession : } \mathrm{ES}=0.66(0.22 \sim 1.1) \\
\text { Adequate prescription : } \mathrm{ES}=0.44(0.30 \sim 0.59) \\
\text { Patients' adherence }: \mathrm{ES}=0.36(0.17 \sim 0.54) \\
\text { Other outcomes : inconclusive (not significant) }\end{array}$ & $\begin{array}{l}\text { DM appears to improve the } \\
\text { detection and care of patients } \\
\text { with depression. }\end{array}$ \\
\hline \multicolumn{4}{|c|}{$\begin{array}{l}\text { Rheumatoid arthritis } \\
\text { Meta-analysis }\end{array}$} \\
\hline $\begin{array}{l}\text { Badam } \\
\text { garav } \\
2003 \mathrm{a}\end{array}$ & $\begin{array}{l}\text { Diseases: rheumatoid arthritis } \\
\text { Interventions: DM program, } \\
\text { duration, number of units of } \\
\text { interventions } \\
\text { Outcomes: functional status }\end{array}$ & $\begin{array}{l}\text { Functional status: } \mathrm{ES}=0.27(\mathrm{CI}-0.01 \sim 0.54) \\
\text { Functional status (HAQ): } \mathrm{ES}=0.16(-0.13 \sim 0.44) \\
\text { Functional status in long intervention duration: } \mathrm{ES}=0.49 \\
(0.12 \sim 0.86)\end{array}$ & $\begin{array}{l}\text { There were limited data to } \\
\text { support or refute the } \\
\text { effectiveness of DM } \\
\text { programs in improving } \\
\text { functional status in patients } \\
\text { with RA. }\end{array}$ \\
\hline \multicolumn{4}{|c|}{$\begin{array}{l}\text { Multiple diseases } \\
\text { Meta-analysis }\end{array}$} \\
\hline $\begin{array}{l}\text { Tsai } \\
2005\end{array}$ & $\begin{array}{l}\text { Diseases: asthma, congestive heart } \\
\text { failure, depression, diabetes } \\
\text { Interventions: CCM, delivery system } \\
\text { design, self-management support, } \\
\text { decision support, clinical information } \\
\text { system, community resources, } \\
\text { healthcare organization } \\
\text { Outcomes: clinical outcome, process } \\
\text { of care }\end{array}$ & $\begin{array}{l}\text { Over all } \\
\text { Clinical outcome: } E S=-0.23(\mathrm{CI}-0.31 \sim-0.15) \\
\text { QOL: } E S=0.11(0.02 \sim 0.21) \\
\text { Process of care: } \mathrm{RR}=1.19(1.10 \sim 1.28) \\
\text { Delivery system design } \\
\text { Clinical outcome: } \mathrm{ES}=-0.21(\mathrm{CI}-0.40 \sim-0.02) \\
\text { Process of care: } \mathrm{RR}=1.16(1.01 \sim 1.34) \\
\text { Self-management } \\
\text { Clinical outcome: } \mathrm{ES}=-0.22(\mathrm{CI}-0.38 \sim-0.05) \\
\text { Decision support } \\
\text { Process of care: } \mathrm{RR}=1.29(1.08 \sim 1.54)\end{array}$ & $\begin{array}{l}\text { Interventions that contain at } \\
\text { least } 1 \text { CCM element improve } \\
\text { clinical outcomes and process } \\
\text { of care (and to a lesser extent, } \\
\text { QOL) for patients with } \\
\text { chronic illness. }\end{array}$ \\
\hline $\begin{array}{l}\text { Krause } \\
2005\end{array}$ & $\begin{array}{l}\text { Diseases: heart disease, asthma, diabetes } \\
\text { Interventions: DM interventions, } \\
\text { self-management, nurse-management, } \\
\text { team-management } \\
\text { Outcomes: medial cost, hospital } \\
\text { admission, clinic visit, emergency visit }\end{array}$ & $\begin{array}{l}\text { Effect size (unbiased): } 0.311 \text { (CI } 0.272 \sim 0.350) \\
\text { The general linear model analysis indicated a statistically } \\
\text { significant difference in disease severity }(\mathrm{p}<0.05) \text {, but not } \\
\text { in the types of diseases and interventions. }\end{array}$ & $\begin{array}{l}\text { DM programs are more } \\
\text { economically effective with } \\
\text { severely ill enrollees, and DM } \\
\text { interventions are most } \\
\text { effective when coordinated } \\
\text { with the overall level of } \\
\text { severity. The findings can be } \\
\text { generalized. }\end{array}$ \\
\hline $\begin{array}{l}\text { Weingar } \\
\text { ten } 2002\end{array}$ & $\begin{array}{l}\text { Diseases: } 118 \text { diseases (diabetes, } \\
\text { depression, asthma, congestive heart } \\
\text { failure, rheumatoid arthritis, } \\
\text { hypertension, COPD, etc) } \\
\text { Interventions: DM program, } \\
\text { education, feedback, reminders, } \\
\text { financial incentives). } \\
\text { Outcomes: disease control, provider } \\
\text { adherence to guidelines, patient } \\
\text { disease control. }\end{array}$ & $\begin{array}{l}\text { Interventions directed at providers } \\
\text { on disease control } \\
\text { Provider education: } E S=0.35(\mathrm{CI} 0.19 \sim 0.51) \\
\text { Provider feedback: } \mathrm{ES}=0.17(0.1 \sim 0.25) \\
\text { Provider reminder: } \mathrm{ES}=0.22(0.1 \sim 0.37) \\
\text { adherence to guidelines } \\
\text { Provider education: } \mathrm{ES}=0.44(0.19 \sim 0.68) \\
\text { Provider feedback: } \mathrm{ES}=0.61(0.28 \sim 0.93) \\
\text { Provider reminder: } \mathrm{ES}=0.52(0.35 \sim 0.89) \\
\text { Interventions directed at patients on disease control } \\
\text { Provider education: } \mathrm{ES}=0.24(0.07 \sim 0.40) \\
\text { Provider feedback: } \mathrm{ES}=0.27(0.17 \sim 0.36) \\
\text { Provider reminder: } \mathrm{ES}=0.40(0.26 \sim 0.54)\end{array}$ & $\begin{array}{l}\text { All studied interventions were } \\
\text { associated with improvements } \\
\text { in provider's adherence to } \\
\text { practice guidelines and } \\
\text { disease controls. The type and } \\
\text { number of interventions } \\
\text { varied greatly, and future } \\
\text { studies should directly } \\
\text { compare different type of } \\
\text { intervention to find the most } \\
\text { effective. }\end{array}$ \\
\hline \multicolumn{4}{|c|}{ Qualitative review } \\
\hline $\begin{array}{l}\text { Ofman } \\
2004\end{array}$ & $\begin{array}{l}\text { Diseases: the same as Weingarten } \\
\text { Interventions: patient education, } \\
\text { provider education, multidisciplinary } \\
\text { team/shared care, provider feedback, } \\
\text { provider reminder, patient financial, } \\
\text { organizational financial, provider } \\
\text { financial } \\
\text { Outcomes: }\end{array}$ & $\begin{array}{l}\text { Substantial improvement (percentage of comparison): } \\
\text { depression } 48 \%(41 / 86) \text {, hyperlipidemia } 45 \%(5 / 11) \text {, CAD } \\
36 \%(24 / 69) \text {, asthma } 25 \%(9 / 36) \text {, rheumatoid arthritis } 24 \% \\
(7 / 29) \text {, back pain } 16 \%(3 / 19) \text {, COPD } 9 \%(2 / 22) \text {, chronic pain } \\
8 \%(1 / 12) \text {. Statistically significant outcomes: } \\
\text { patient satisfaction } 71 \%(12 / 17) \text {, patient adherence } 47 \% \\
(17 / 36) \text {, disease control } 45 \%(33 / 74) \text {, provider adherence } 40 \% \\
(14 / 35) \text {, patient knowledge } 31 \%(4 / 13) \text {, morbidity } 29 \%(7 / 24) \text {, } \\
\text { mortality } 24 \%(4 / 17) \text {, QOL } 16 \%(5 / 31) \text {, other utilization } 16 \% \\
(4 / 25) \text {, costs: } 14 \%(1 / 7) \text {, emergency visit } 11 \%(1 / 9) \text {, } \\
\text { hospitalization } 11 \%(3 / 28)\end{array}$ & $\begin{array}{l}\text { DM programs were } \\
\text { associated with marked } \\
\text { improvements in many } \\
\text { different processes and } \\
\text { outcomes of care. Few studies } \\
\text { demonstrated a notable } \\
\text { reduction in costs. }\end{array}$ \\
\hline
\end{tabular}


Table 3. Summary of important outcomes in disease management programs

\begin{tabular}{|c|c|c|c|c|c|c|c|c|}
\hline Article & Mortality & $\begin{array}{l}\text { Health } \\
\text { outcome }\end{array}$ & Process & QOL & Satis-faction & $\begin{array}{l}\text { Knowledge } \\
\text { or life-style }\end{array}$ & $\begin{array}{l}\text { Health } \\
\text { services }\end{array}$ & Costs \\
\hline \multicolumn{9}{|l|}{ CHD } \\
\hline \multicolumn{9}{|l|}{ Meta-analysis } \\
\hline Göhler 2006 & $\mathrm{O}$ & - & - & - & - & - & $\mathrm{O}$ & - \\
\hline Roccaforte 2005 & $\mathrm{O}$ & - & O & - & - & - & O & - \\
\hline Whellan 2005 & $?$ & - & $?$ & $\triangle ?$ & - & - & O & $?$ \\
\hline Phillips 2005 & $\times$ & - & - & $\triangle$ & - & - & $\times$ & $?$ \\
\hline Gonseth 2004 & $O^{*}$ & - & - & - & - & - & O & $\triangle$ \\
\hline McAlister 2001b & $\times$ & $\mathrm{O}$ & O & $\triangle$ & - & - & O & $\triangle ?$ \\
\hline McAlister 2001a & $x$ & - & $\triangle$ & $\triangle ?$ & - & - & O & $?$ \\
\hline \multicolumn{9}{|l|}{ Qualitative review } \\
\hline Yu 2006 & $?$ & - & - & $\triangle$ & - & - & $\triangle$ & $\triangle$ \\
\hline Jerant 2005 & $?$ & - & - & $?$ & - & - & $\triangle$ & $?$ \\
\hline \multicolumn{9}{|l|}{ Ara 2004} \\
\hline Congestive heart failure & - & $\triangle ?$ & $\triangle ?$ & - & - & - & $\triangle ?$ & - \\
\hline Hypertension & - & $\triangle$ & $\triangle ?$ & $\triangle ?$ & - & $\triangle ?$ & $\triangle ?$ & $\triangle$ \\
\hline Hyperlipidemia & - & $\triangle ?$ & $\triangle ?$ & - & - & $\triangle ?$ & - & - \\
\hline \multicolumn{9}{|l|}{ COPD and asthma } \\
\hline \multicolumn{9}{|l|}{ Meta-analysis } \\
\hline Lemmens 2009 & - & $x$ & $\triangle ?$ & O & $\triangle ?$ & $\triangle ?$ & $\mathrm{O}$ & - \\
\hline Peytremann-Bridevaux 2008 & $\times$ & O & - & $\triangle$ & - & $?$ & $\triangle$ & - \\
\hline Adams 2007 & $\times$ & $x$ & - & $\triangle$ & - & $\triangle$ & O & $\triangle$ \\
\hline Talyor 2005 & $\times$ & $x$ & - & $x$ & - & $\triangle ?$ & $\triangle ?$ & - \\
\hline Sin 2003 & $\times$ & - & - & O & - & - & $\times$ & - \\
\hline \multicolumn{9}{|l|}{ Qualitative review } \\
\hline Maciejewski 2009 & - & $\triangle$ & $\triangle$ & $\triangle$ & - & - & $\triangle$ & - \\
\hline Steuten 2009 & $\times$ & $\times$ & $?$ & $?$ & - & $\times$ & $\triangle$ & $?$ \\
\hline Niesink 2008 & - & - & - & $\triangle$ & - & - & - & - \\
\hline Steuten 2007 & - & $x$ & $?$ & $\triangle$ & $\triangle ?$ & - & $\triangle$ & $\triangle ?$ \\
\hline \multicolumn{9}{|l|}{ Diabetes } \\
\hline \multicolumn{9}{|l|}{ Meta-analysis } \\
\hline Knight 2005 & - & O & $\triangle$ & $\triangle ?$ & - & $\triangle ?$ & $\triangle ?$ & - \\
\hline Noris 2002 & - & $\mathrm{O}$ & $\mathrm{O}$ & $\triangle ?$ & $\triangle ?$ & $?$ & $\triangle ?$ & $?$ \\
\hline \multicolumn{9}{|l|}{ Depression } \\
\hline \multicolumn{9}{|l|}{ Meta-analysis } \\
\hline Neumeyer-Gromen 2004 & - & O & O & $\triangle$ & O & - & - & O \\
\hline Badamgarav 2003b & - & O & O & $\times$ & $\mathrm{O}$ & - & $\times$ & $\times$ \\
\hline \multicolumn{9}{|l|}{ Rheumatoid arthritis } \\
\hline \multicolumn{9}{|l|}{ Meta-analysis } \\
\hline Badamgarav 2003a & - & O & - & - & - & - & - & - \\
\hline \multicolumn{9}{|l|}{ Multiple diseases } \\
\hline \multicolumn{9}{|l|}{ Meta-analysis } \\
\hline Tsai 2005 & - & O & O & O & - & - & - & - \\
\hline Krause 2005 & - & - & - & - & - & - & - & $\mathrm{O}^{\#}$ \\
\hline \multicolumn{9}{|l|}{ Weingarten 2002} \\
\hline Overall & - & - & $\mathrm{O}$ & - & - & $\mathrm{O}$ & - & - \\
\hline CHD & - & - & $\mathrm{O}$ & - & - & 0 & - & - \\
\hline Diabetes & - & - & O & - & - & $\mathrm{O}$ & - & - \\
\hline Depression & - & - & $\mathrm{O}$ & - & - & 0 & - & - \\
\hline COPD & - & - & - & - & - & $x$ & - & - \\
\hline Rheumatoid arthritis & - & - & O & - & - & $?$ & - & - \\
\hline \multicolumn{9}{|l|}{ Qualitative review } \\
\hline Ofman 2004 & $?$ & $?$ & $\triangle$ & - & $\triangle$ & $\triangle$ & $?$ & $?$ \\
\hline
\end{tabular}


Table 4. Evaluation of intervention features, quality of studies, and economics for disease management

\begin{tabular}{|c|c|c|c|}
\hline Article & Intervention features & Quality of studies & Economics \\
\hline \multicolumn{4}{|l|}{ CHD } \\
\hline \multicolumn{4}{|l|}{ Meta-analysis } \\
\hline Göhler 2006 & $\begin{array}{l}\text { Multidisciplinary team and personal } \\
\text { post-discharge contact were more effective } \\
\text { and suggested as factors explaining } \\
\text { heterogeneity in re-hospitalization between } \\
\text { studies. }\end{array}$ & - & - \\
\hline $\begin{array}{l}\text { Roccaforte } \\
2005\end{array}$ & $\begin{array}{l}\text { High quality studies and multidisciplinary } \\
\text { programs appeared to be more consistently } \\
\text { associated with a beneficial effect on } \\
\text { mortality and health failure related } \\
\text { re-hospitalization rates. }\end{array}$ & $\begin{array}{l}\text { The quality of each study was evaluated } \\
\text { according to component approach, } \\
\text { examining randomization, blinding and } \\
\text { so on. Thirty percent of studies were } \\
\text { decided to be of high quality. }\end{array}$ & - \\
\hline Whellan 2005 & $\begin{array}{l}\text { Interventions using clinic follow up by } \\
\text { specialist, home visit, or telephone follow } \\
\text { up significantly decreased all-cause } \\
\text { hospitalization. }\end{array}$ & - & $\begin{array}{l}\text { Although most of studies reported a } \\
\text { cost for providing the intervention, it } \\
\text { only reflected estimates of direct } \\
\text { personal expenses. Indirect expenses } \\
\text { were not included. }\end{array}$ \\
\hline Phillips 2005 & $\begin{array}{l}\text { Interventions with hospital discharge } \\
\text { planning were more effective in } \\
\text { readmission rate. }\end{array}$ & $\begin{array}{l}\text { In assessing methodological quality, } \\
\text { the Jadad score for each study was } \\
\text { calculated. The median Jadad score } \\
\text { was } 3.5 \text {. Sixty-seven percent of } \\
\text { studies were of high quality. }\end{array}$ & $\begin{array}{l}\text { Only three programs reported } \\
\text { complete data for the cost of care } \\
\text { (initial hospital care, intervention } \\
\text { costs, out patient care, and charges for } \\
\text { readmissions). The potential savings } \\
\text { was observed, but not significant. }\end{array}$ \\
\hline Gonseth 2004 & - & $\begin{array}{l}\text { The study quality was assessed by } \\
\text { the Jadad scale for randomized } \\
\text { controlled trial. Only } 11 \text { of } 27 \text { trials } \\
\text { attained a core of } 3 \text { on the scale. } \\
\text { Among } 27 \text { non-randomized trials, no } \\
\text { study adjusted for confounding factors. }\end{array}$ & $\begin{array}{l}\text { Thirteen studies assessed the cost of } \\
\text { DM programs. Only several studies } \\
\text { considered intervention costs besides } \\
\text { healthcare costs. }\end{array}$ \\
\hline $\begin{array}{l}\text { McAlister } \\
2001 \mathrm{~b}\end{array}$ & - & - & $\begin{array}{l}\text { Only three trials described the costs of } \\
\text { interventions. Two reported cost } \\
\text { savings, but none performed formal } \\
\text { cost-effectiveness analysis. }\end{array}$ \\
\hline $\begin{array}{l}\text { McAlister } \\
\text { 2001a }\end{array}$ & $\begin{array}{l}\text { Multidisciplinary team providing } \\
\text { specialized follow-up reduced the risk of } \\
\text { hospitalization. }\end{array}$ & - & $\begin{array}{l}\text { Only one trial reported cost saving. } \\
\text { There is no detailed cost description. }\end{array}$ \\
\hline \multicolumn{4}{|c|}{ Qualitative review } \\
\hline Yu 2006 & $\begin{array}{l}\text { Characteristics of effective DM programs } \\
\text { were analyzed by case-control like } \\
\text { analysis. The difference was observed in } \\
\text { several items including counseling in } \\
\text { hospital by allied health and exercise } \\
\text { counseling, but none of them were } \\
\text { statistically significant. }\end{array}$ & - & $\begin{array}{l}\text { Seven of eight effective programs } \\
\text { were indicated to be cost saving. } \\
\text { However, there is no information on } \\
\text { costs, except cost per case. }\end{array}$ \\
\hline Jerant 2005 & - & $\begin{array}{l}\text { The quality of studies was assessed } \\
\text { according to the User's Guide to } \\
\text { Medical Literature. Only eight of } 33 \\
\text { trials were judged to be of acceptable. }\end{array}$ & $\begin{array}{l}\text { Reduction of acute care costs and } \\
\text { medical care charges were mentioned } \\
\text { based on systematic reviews. There is } \\
\text { no detailed information on costs. }\end{array}$ \\
\hline Ara 2004 & - & & $\begin{array}{l}\text { One study indicated cost-effectiveness } \\
\text { based on blood pressure reduction. } \\
\text { The other three studies mentioned } \\
\text { expenditure per capita, medical care } \\
\text { costs and cost of anti-hypertensive } \\
\text { therapy, but there was no detailed } \\
\text { information on costs. }\end{array}$ \\
\hline
\end{tabular}




\begin{tabular}{|c|c|c|c|}
\hline Article & Intervention features & Quality of studies & Economics \\
\hline \multicolumn{4}{|c|}{ COPD \& asthma } \\
\hline \multicolumn{4}{|c|}{ Meta-analysis } \\
\hline $\begin{array}{l}\text { Lemmens } \\
2009\end{array}$ & $\begin{array}{l}\text { Triple interventions (patient-related, } \\
\text { professional-directed and organizational } \\
\text { interventions) including case } \\
\text { management showed significant } \\
\text { difference in quality of life, although } \\
\text { double interventions did not. Double } \\
\text { interventions including a pharmacist } \\
\text { showed significant difference in quality } \\
\text { of life, although triple interventions did } \\
\text { not. However, a qualitative comparison } \\
\text { suggested more significant effects of } \\
\text { triple rather double interventions. }\end{array}$ & $\begin{array}{l}\text { Study quality was assessed with the } \\
\text { Health Technology Assessment, Disease } \\
\text { Management instrument ( } 0 \text { to } 100 \\
\text { points). Studies of inferior quality (below } \\
50 \text { points) were excluded. Forty-two } \\
\text { percent of studies were evaluated as good } \\
\text { quality. }\end{array}$ & - \\
\hline $\begin{array}{l}\text { Peytremann } \\
\text {-Bridevaux } \\
2008\end{array}$ & - & $\begin{array}{l}\text { The quality of trials was assessed using } 3 \\
\text { different instruments (Jadad score, } \\
\text { qualitative categories by Cochrane } \\
\text { Collaboration. and Health Technology } \\
\text { Assessment, Disease Management } \\
\text { instrument). The mean Jadad score was } \\
\text { 2.4. Studies with high quality in other } \\
\text { scales were less than half. }\end{array}$ & - \\
\hline $\begin{array}{l}\text { Adams } \\
2007\end{array}$ & $\begin{array}{l}\text { The relative risk of emergency visits and } \\
\text { hospitalizations were significantly low } \\
\text { for multi-component studies. }\end{array}$ & $\begin{array}{l}\text { The US Preventive Task Force criteria } \\
\text { were used. Only one study was evaluated } \\
\text { as good and four studies were as fair } \\
\text { among } 20 \text { RCTs. }\end{array}$ & $\begin{array}{l}\text { Among } 4 \text { trials reporting costs, three } \\
\text { demonstrated a range of } 34 \% \text { to } 70 \% \\
\text { reduction in health care costs in the } \\
\text { intervention groups, predominantly } \\
\text { because of reduced hospitalizations. }\end{array}$ \\
\hline Talyor 2005 & - & $\begin{array}{l}\text { The Delphi list and the Jadad criteria } \\
\text { were used. Most of } 9 \text { trials had potential } \\
\text { methodological limitations. }\end{array}$ & - \\
\hline Sin 2003 & - & $\begin{array}{l}\text { The scoring system was not used to } \\
\text { evaluate the quality of the trials. The } \\
\text { authors restricted the analysis to trials with } \\
\text { randomization, placebo-control, blind } \\
\text { ascertainment of end point, and so on. }\end{array}$ & - \\
\hline \multicolumn{4}{|c|}{ Qualitative review } \\
\hline $\begin{array}{l}\text { Maciejewski } \\
2009\end{array}$ & - & $\begin{array}{l}\text { The quality of study was examined in } \\
\text { terms of study design, intervention } \\
\text { description, and statistical adjustment. } \\
\text { The studies' quality was poor in these } \\
\text { respects. }\end{array}$ & - \\
\hline $\begin{array}{l}\text { Steuten } \\
2009\end{array}$ & - & $\begin{array}{l}\text { The methodological quality of the } \\
\text { articles was evaluated with the Health } \\
\text { Technology Assessment, Disease } \\
\text { Management instrument ( } 0 \text { to } 100 \\
\text { points). The overall mean score was } 67.6 \text {. } \\
\text { Forty-seven percent of studies were of } \\
\text { good quality. }\end{array}$ & $\begin{array}{l}\text { Three studies, presenting cost data, } \\
\text { showed difference observed (e.g., } \\
\text { prescription costs, hospitalization } \\
\text { related costs). However, none of them } \\
\text { reported significant changes in total } \\
\text { costs. }\end{array}$ \\
\hline $\begin{array}{l}\text { Niesink } \\
2008\end{array}$ & - & $\begin{array}{l}\text { The } 11 \text { criteria were used to assess } \\
\text { methodological quality. The average score } \\
\text { was } 5.8 \text {. The proportion of studies with } \\
\text { high score (i.e., more than six) was } 60 \% \text {. }\end{array}$ & - \\
\hline $\begin{array}{l}\text { Steuten } \\
2007\end{array}$ & - & $\begin{array}{l}\text { The methodological quality of the articles } \\
\text { was evaluated with the Health Technology } \\
\text { Assessment, Disease Management } \\
\text { instrument ( } 0 \text { to } 100 \text { points). The overall } \\
\text { mean score was } 60.0 \text {. Only three studies } \\
\text { showed good quality. }\end{array}$ & $\begin{array}{l}\text { In one study, significant decrease in } \\
\text { annual total costs was reported. } \\
\text { However, using total costs as a single } \\
\text { primary outcome measure poses a } \\
\text { threat to the validity of outcome. }\end{array}$ \\
\hline
\end{tabular}




\begin{tabular}{|c|c|c|c|}
\hline Article & Intervention features & Quality of studies & Economics \\
\hline \multicolumn{4}{|l|}{ Diabetes } \\
\hline \multicolumn{4}{|c|}{ Meta-analysis } \\
\hline Knight 2005 & - & - & - \\
\hline Noris 2001 & - & $\begin{array}{l}\text { Studies met the minimum quality } \\
\text { standard of the evidence-based Guide to } \\
\text { Community Preventive Services, method. }\end{array}$ & $\begin{array}{l}\text { One study showed no difference in } \\
\text { average cost between intervention and } \\
\text { control groups after } 2 \text { years. The other } \\
\text { cost-benefit study showed incremental } \\
\text { benefit cost ratio of } 1.86 \text {. Both studies } \\
\text { were classified as good. }\end{array}$ \\
\hline
\end{tabular}

\section{Depression}

Meta-analysis

Neumeyer-

Gromen 2004

The validity assessment of each study was conducted on the basis of the Cochrane Collaboration Handbook. Except for three studies with quality of $\mathrm{A} / \mathrm{B}, \mathrm{B}$ and $\mathrm{B} / \mathrm{C}$, all other studies were those of best quality (A).
Based on 6 cost-effectiveness/cost-utility analysis, overall cost-utility ratios ranged between $\$ 9,051$ and $\$ 49,500$ per quality adjusted life year. The studies were evaluated by NHS EED economists as mostly valid and reliable.

All three programs measured total health services cost associated with treatment and indicated that program participants incurred higher costs. But the effect was not statistically significant.

\section{Rheumatoid arthritis}

Meta-analysis

Based on the number of units of interventions, the studies offering Badamgarav equal or less than 6 units of 2003a interventions were associated with higher effect, although estimates did not reach statistical significance.

\section{Multiple diseases}

Meta-analysis

Four elements of the CCM (delivery system design, self-management

Tsai 2005 support, decision support, and clinical information system) were associated with better outcomes and processes.

Statistically significant difference of effect size was observed by DM

Krause 2005 interventions (e.g., team-managed) and disease severity, but the former was not found after the latter was taken into consideration.

Education, feedback and reminder for provider, as well as education,

Weingarten reminder and financial incentives, were 2002 all associated with improvement in provider adherence to guidelines and/or patient disease control.

\section{Qualitative review}

Ofman 2004
In assessing methodological quality, the Jadad score for each study was calculated. Among 93 RCTs, only 32\% scored 3, and none scored higher than 3 . However, double blinding is rarely possible in studies of organizational interventions.
The quality of clinical trials was assessed using criteria described by Jadad.
As direct economic measures, 4 items (i.e., medical cost, hospital admissions or readmissions, physician office or clinic visit, and emergency department visits) were used. The individual effect size values were averaged and included as one construct.

Utilization and cost-related outcomes showed benefit in relatively few studies.

DM: disease management, DMAA: Disease Management Association of America, CCM: chronic care model, RCT: randomized controlled trial, CT: controlled trial, HF: heart failure, COPD: chronic obstructive pulmonary disease 